\title{
EL OBJETO DE PROHIBICIÓN EN EL DELITO DE REBELIÓN DEL ART. 472 CP DESDE LA ÓPTICA DEL MODELO DE ESTADO SOCIAL Y DEMOCRÁTICO DE DERECHO PREVISTO CONSTITUCIONALMENTE
}

\author{
Joaquim Bages Santacana *
}

Resumen: Durante meses el delito de rebelión del art. 472 CP ha ocupado una posición central dentro del intenso debate desarrollado en el seno de la sociedad española a propósito de los hechos ocurridos en relación con el llamado "proceso independentista catalán". Pese a ser verdaderamente escasos los estudios que analizan este delito de forma mínimamente pormenorizada, el propio diseño constitucional conduce a interpretarlo de forma restrictiva puesto que, si la conducta ha de ser adecuada para destruir el sistema jurídico-político vigente, tan sólo pueden ser constitutivos de dicha infracción los alzamientos públicos y violentos idóneos para provocar la declaración de estado de sitio pre-

\section{Recibido: julio 2018. Aceptado: octubre 2018}

* Profesor de Derecho penal. ID ORCID: 0000.0003.4200.7158

Departamento de Derecho penal y Criminología, y Derecho internacional público y Relaciones internacionales. Facultad de Derecho de la Universidad de Barcelona. Avenida Diagonal, nº 684, Barcelona (08028). Email: bages@ub.edu 
vista en el art. $116 \mathrm{CE}$. En cuanto a las modalidades comisivas, tanto la violencia física como la psicológica pueden ser medios eficaces para generar este potencial peligro para el orden constitucional.

Palabras clave: delito de rebelión, violencia, delitos contra la Constitución, delito de sedición, actos preparatorios punibles.

\author{
THE OBJECT OF PROHIBITION IN THE CRIME OF \\ REBELLION OF ART. 472 CP FROM THE PERSPECTIVE OF \\ THE MODEL OF SOCIAL AND DEMOCRATIC STATE OF LAW \\ CONSTITUTIONALLY ENVISAGED
}

\begin{abstract}
For months the crime of rebellion of art. 472 CP has occupied a central position within the intense debate developed in the Spanish society regarding the events that occurred in relation to the so-called "Catalan independence process". Although the studies that analyze this crime in a minimally detailed way are really scarce, the constitutional design itself leads to interpreting it in a restrictive way since, if the conduct has to be adequate to destroy the legal-political system in force, only the public and violent uprisings suitable to provoke the declaration of state of siege foreseen in art. 116 CE can be constitutive of said infraction. As for the comissive modalities, both physical and psychological violence can be effective means to generate this potential danger for the constitutional order.
\end{abstract}

Keywords: crime of rebellion, violence, crimes against the Constitution, crime of sedition, punishable preparatory acts.

\title{
I. Origen de la (sobrevenida) actualidad de este delito
}

En los últimos tiempos el delito de rebelión del art. 472 $\mathrm{CP}$ ha despertado un interés hasta ahora inusitado, no sólo en el ámbito estrictamente académico, sino en el conjunto de la opinión pública española, como consecuencia de los procedimientos judiciales seguidos contra diferentes líderes políticos por su implicación en el llamado "proceso independentista catalán", mediante el que una parte del territorio nacional se segregaría del resto para constituirse en Estado independiente, eventualmente al 
margen de los cauces legales ${ }^{1}$. En síntesis, a juicio de los sectores más beligerantes con el movimiento secesionista, a partir del año 2013 los supuestos rebeldes habrían impulsado, a través de las instituciones, fuerzas políticas y asociaciones que controlaban, un proceso de transición nacional de Catalunya que debía culminar, de manera negociada o unilateral, en la constitución de esta parte del territorio en Estado independiente ${ }^{2}$.

Los presuntos rebeldes, amparándose en la legitimidad política derivada del derecho a la autodeterminación de los catalanes proclamado en la Resolución del Parlamento de Catalunya 5/X, de 23 de enero de 2013, anulada mediante la STC 42/2014, de 25 de marzo, habrían promovido el ejercicio de un pretendido derecho a decidir del pueblo catalán capaz de desembocar en la constitución de esta Comunidad Autónoma en sujeto político y jurídico soberano. Los supuestos alzados habrían contemplado distintos procedimientos para la constitución del nuevo Estado, de modo que, tras constatar que la independencia de Catalunya no podía alcanzarse mediante un marco de colaboración negociada con el Gobierno español, habrían optado por forzar a éste a asumir la nueva situación de hecho cuya creación buscaban. Para superar este escenario de enfrentamiento institucional, habrían sido factores decisivos el apoyo ciudadano y la creación de las estructuras de Estado precisas para una independencia no pactada. Este apoyo ciudadano se habría exteriorizado, de forma particularmente nítida, a través de la movilización popular masiva del día 20 de septiembre de 2017 con la que se habría tratado de impedir el registro, por parte de la correspondiente comitiva

1 Sobre algunos de los aspectos procesales más controvertidos respecto este caso concreto, singularmente sobre los relacionados con la competencia objetiva para el conocimiento de los hechos, Dopico Gómez-Aller, J.: “¿Es competente la Audiencia Nacional para conocer de los delitos de rebelión y de (algunos de) los delitos de sedición?", en Revista Electrónica de Ciencia Penal y Criminología, $\mathrm{n}^{\mathrm{o}} 19-17,2017$, pp. 2 y ss.

2 Según se indica en el ATS de 21 de marzo de 2018, por el que se acuerda procesar a los investigados por varios delitos, algunos de ellos por el de rebelión. 
judicial, de la sede de la Consejería de Economía y Hacienda de la Generalitat de Catalunya.

Por su parte, con la declaración unilateral de independencia del Parlamento autonómico de 27 de octubre de 2017, por la que se establecía la República catalana como "Estado independiente y soberano, de derecho, democrático y social", las instituciones de autogobierno de Catalunya habrían intentado desvincularse de manera definitiva del aparato institucional del Estado español y de su Ordenamiento jurídico, con la consiguiente falta de reconocimiento de la autoridad del mismo. Sin embargo, antes de que esta declaración de independencia de carácter conflictivo pudiera desarrollarse a través de un proceso constituyente dirigido a la promulgación del Ordenamiento jurídico de la República catalana, en virtud del art. $155 \mathrm{CE}$ el Gobierno español adoptó, con la aprobación por mayoría absoluta del Senado, varias medidas tendentes a obligar a la Generalitat de Catalunya a cumplir con lo que en su momento se consideraron sus deberes constitucionales, entre ellas el cese del Presidente del Gobierno de la Generalitat y de todos sus consejeros (Orden del Ministerio de la Presidencia y para las Administraciones Territoriales 1034/2017, de 27 de octubre, por el que se publica el Acuerdo del Consejo de Ministros de 21 de octubre de 2017).

$\mathrm{Al}$ margen de lo que finalmente se decida en relación con este caso particular, lo cierto es que de modo repentino el delito de rebelión ha captado la atención de la doctrina, sustrayéndolo ésta del injustificado ostracismo doctrinal en el que hasta ahora se encontraba. Las cuestiones más controvertidas que en el referido caso concreto suscita este delito son extrapolables a un análisis general del mismo al tratar, fundamentalmente, en primer lugar, sobre el contenido y alcance de los medios comisivos, al exigirse que el alzamiento público se perpetre con "violencia"; en segundo lugar, sobre el establecimiento del momento en el que se inicia la ejecución del tipo, teniendo en cuenta la punibilidad de determinados actos preparatorios del mismo; y, en tercer lugar, sobre la determinación del bien jurídico, de la que depende la catalogación del tipo como delito de peligro abstrac- 
to y la carga mínima de ofensividad de la conducta prohibida. El examen de estos problemas en relación con este caso concreto ha puesto de manifiesto la ausencia de pautas hermenéuticas razonablemente consensuadas para la aplicación del delito en cuestión. A su vez, este vacío doctrinal ha alentado afirmaciones apriorísticas con unos efectos perjudiciales especialmente intensos a la vista de la apremiante urgencia de un debate mediático incompatible, seguramente, con la seriedad y serenidad que exigen unas mínimas cuotas de rigor científico.

\section{Objeto de estudio y presupuestos metodológicos}

En su redacción actual, cuyo origen se remonta a la promulgación del $\mathrm{CP}$ vigente, hasta la fecha, el delito de rebelión nunca ha sido aplicado. La ausencia de precedentes jurisprudenciales, sumada a la escasez de estudios que lo examinen a fondo, justifica la elaboración de un análisis sosegado del mismo a los efectos de racionalizar sus rasgos esenciales con los principios limitadores del poder punitivo propios de un Estado social y democrático de Derecho. Desde esta perspectiva, las páginas que siguen se destinarán a la delimitación de la materia de prohibición en esta tipología delictiva a partir de su anclaje constitucional. En concreto, a través de los criterios axiológicos suministrados, principalmente, por los principios de legalidad, lesividad y proporcionalidad.

En esta línea, se reflexionará acerca de la eventual eficacia reductora de la tipicidad procedente de un análisis del delito de rebelión desde una óptica teleológico-funcionalista ${ }^{3}$ en la que

3 La introducción de la perspectiva político-criminal en el Derecho Penal es una de las principales consecuencias de la evolución de las bases políticoideológicas del sistema dogmático, como muestran claramente los pensamientos de Roxin y MiR PUIG. Añade este último que el progreso científicotecnológico ha aproximado el Derecho Penal a la realidad, lo que ha permitido tomar conciencia de la necesidad de que la consecuencia dogmática solucione la cuestión material de acuerdo con valoraciones político-criminales. Vid. Roxin, C.: Política Criminal y estructura del delito. Elementos 
la relevancia penal de la conducta dependa de las finalidades de protección del tipo, puestas en relación con el conjunto de mecanismos autoprotectores de los que dispone el sistema constitucional. En relación con este particular, va a sostenerse la tesis de que no todas las conductas formalmente subsumibles en el tipo lo realizan en sentido material, al no colocar todas ellas la indemnidad del bien jurídico protegido en una zona de incertidumbre penalmente trascendente ${ }^{4}$. En consecuencia, se intentará determinar la gravedad mínima a revestir por el riesgo de lesión del bien jurídico para ingresar en la esfera penal ${ }^{5}$.

del delito en base a la Política Criminal, Barcelona, 1992, pp. 36 y ss.; MiR Puig, S.: Introducción a las bases del Derecho Penal, Barcelona, 1976, pp. 324 y ss.

4 Señala Corcoy Bidasolo, M.: El delito imprudente. Criterios de imputación del resultado, Buenos Aires, 2005, pp. 303 y 304, que "en esta dirección, se ha hablado también de 'congruencia social' como límite de la tipicidad. En los casos en que la conducta, formalmente, realiza un elemento típico, comprendido en el tenor literal, no entrará dentro del tipo si esa conducta es 'socialmente congruente'. Una conducta es socialmente congruente cuando es exigida, por la ética-social y cuando es irrelevante, desde el punto de vista de un mínimo daño. Esta segunda acepción de la 'congruencia social' de la conducta, en base a su irrelevancia, se acerca al concepto del principio de insignificancia. Mir Puig, entiende que el principio de insignificancia -Geringfügigkeitsprinzip-, se distingue de la adecuación social en que 'no supone la total aprobación social de la conducta, sino sólo una relativa tolerancia de la misma por su escasa gravedad'. El principio de insignificancia, en estos casos, permite la exclusión del tipo".

5 Relativiza el origen liberal del concepto de bien jurídico, al tiempo que revisa a la baja su potencial crítico, PAwLIK, M.: "El delito, ¿lesión de un bien jurídico?", en InDret, n 2, 2016, pp. 7 y ss. En su opinión, el defecto principal del pensamiento del bien jurídico reside en que no suministra criterios fiables para identificar qué intereses son merecedores de tutela penal en el marco de una sociedad compleja que contempla el mantenimiento de estados polifacéticos.

En un sentido parecido, se interroga Амвоs, K.: "Bases teóricas para determinar la 'función global' del Derecho penal internacional. Una segunda contribución para una teoría coherente del Derecho penal internacional”, en InDret, $\mathrm{n}^{\circ} 10,2013$, p. 354, acerca de si el concepto de bien jurídico confiere un criterio (normativo) para decidir qué intereses deben ser protegidos por la ley penal y cuáles no. 
La adopción de una óptica teleológico-funcionalista conduce a introducir una dimensión material-subjetiva en el sistema dogmático, en la que las referencias axiológicas de éste se orientan a sus específicas finalidades de protección ${ }^{6}$. Según ello, en el terreno epistemológico se recurre a un paradigma gnoseológico de carácter no ontológico, lo que obliga a reconocer el carácter normativo de todos los enunciados jurídicos ${ }^{7}$. Esta circunstancia, tomada como premisa metodológica, en cierta medida diluye las fronteras entre las fronteras entre la vertiente fáctica y la normativa de las disposiciones legales, al descubrir la esencia valorativa de todas ellas. Ello no obstante, pese a la introducción de una dimensión valorativa en la facticidad propia del Derecho, con la consiguiente normativización de las bases descriptivas de la dogmática, siguen existiendo límites a la espiritualización del sentido material de las proposiciones legales ${ }^{8}$. Lo específico de este modelo científico es que el intérprete no se limita a la descripción, a la explicación del sistema positivo de normas en una sociedad dada, sin introducir consideraciones valorativas, sino que analiza el Derecho vigente sin renunciar de entrada a la introducción de criterios políticos de validez y legitimidad.

6 En palabras de EmBid Irujo, A.: La constitucionalización de la crisis económica, Madrid, 2012, pp. 45 y 46, la afirmación de la libertad del ciudadano es el objetivo fundamental de cualquier constitucionalismo, de cualquier proceso de "constitucionalización".

7 Como señala Silva SÁnchez, J.: Fundamentos del Derecho penal de la Empresa, Madrid / Montevideo / Buenos Aires, 2013, pp. 3 y ss., la teoría del delito no pretende únicamente levantar un edificio teórico coherente, exento de contradicciones en un plano abstracto. Por el contrario, ha de tener en cuenta el caso concreto y su demanda de resolución, por lo que no ha de intentar sustraerse a la tensión consustancial existente entre el pensamiento sistemático y el pensamiento tópico.

8 Los contenidos proporcionados por la dogmática carecen de validez universal o absoluta, lo que obliga a rechazar la existencia de estructuras objetivas anteriores al proceso de conocimiento y, en consecuencia, a reconocer el relativismo gnoseológico de toda disciplina cuya metodología no sea de carácter empírico. Este punto de partida justifica la adopción de un método dogmático jurídico-normativo con aportaciones axiológicas de la Política criminal. 
Lo anterior lleva a expresar en términos menos absolutos las cuotas de neutralidad científica que en principio está destinada a alcanzar la dogmática penal. Y, simultáneamente, determina que una de las principales consecuencias de la evolución de las bases político-ideológicas del sistema dogmático sea la introducción de la perspectiva político-criminal en el Derecho penal ${ }^{9}$. Según ello, si la cuestión material debe resolverse con arreglo a parámetros político-criminales, el injusto del delito de rebelión sólo puede sustantivarse desde la óptica de las garantías del Derecho penal en un Estado social y democrático de Derecho, como son las de legalidad, lesividad o proporcionalidad. Desde este punto de vista, el contenido del tipo depende, en síntesis, de

En esta línea, según Mir PuIG, S.: Introducción a las bases del Derecho Penal, Barcelona, 1976, p. 346, "para que la Política criminal con base criminológica pueda penetrar fundadamente en la labor dogmática, es preciso reconocer previamente la vigencia de los otros postulados requeridos más arriba para una metodología jurídico-penal realista. En efecto, sin el aparato conceptual que ofrece una concepción de la ciencia del Derecho como ciencia social, la comunicación de Política criminal y dogmática tropieza con el decisivo obstáculo que supone la separación del mundo de las normas del mundo de lo social. Tomada, en cambio, la norma como regulación de los procesos sociales, respecto de los cuales cumple una determinada función social, queda abierta la puerta a la confrontación, en términos conceptuales homogéneos, con las exigencias político-criminales. Pues aquella función social no es sino expresión del significado político-criminal de la norma. Por otra parte, el entendimiento realista del proceso de aplicación de la ley, al imponer la necesidad de tender a las exigencias de la realidad regulada por la ley, fundamenta la legitimidad de la perspectiva político-criminal en la aplicación de la ley. Si el tenor de la ley fuera el único elemento de su concreción práctica, no sería lícito acudir a las necesidades político-criminales de los casos particulares". Vid. también Silva Sánchez, J.: Aproximación al Derecho penal contemporáneo, Montevideo / Buenos Aires, 2010, pp. 116 y ss.; Corcoy Bidasolo, M.: El delito imprudente. Criterios de imputación del resultado, Buenos Aires, 2005, pp. 36 y ss.

9 Esta postura sería compatible con una concepción de los bienes jurídicopenales según la que éstos representan uno o varios valores que, al formar parte de las reglas de cooperación social más esenciales, son merecedores de una protección reforzada a través del ejercicio de ius puniendi del Estado. Vid. González Gutiérrez-Barquín, P.: Manual de Delitos contra la Hacienda Pública, Madrid, 2004, pp. 55 y ss. 
los parámetros valorativos inspiradores de la decisión en la que se fundamenta su incriminación ${ }^{10}$.

Sentado lo anterior, el principio de insignificancia puede constituir una valiosa pauta para facilitar el acotamiento del círculo de conductas proscritas por esta figura a partir de una interpretación restrictiva de la misma. A la vista de la severidad de las penas de prisión previstas para esta infracción (de hasta 30 años), razones vinculadas al principio de proporcionalidad en principio conducen a reservarla para las formas más graves de ataque al bien jurídico ${ }^{11}$. Ahora bien, para sustentar esta conclusión deberá establecerse cuál es la distinción, con las consiguientes relaciones concursales, entre este delito y el de sedición del art. 544 CP. Por el momento basta con apuntar que las diferencias entre ambas hipótesis delictivas no se residencian en los medios empleados, sino en el distinto bien jurídico atacado $y$, por ende, en la distinta finalidad perseguida por el agente. En este orden de cosas, podría sostenerse que el círculo de conductas objetivamente adecuadas para lesionar el bien jurídico es muy restringido por la enorme dificultad de proceder a un efectivo menoscabo del mismo, aunque éste sea de carácter leve. En consecuencia, será extremadamente difícil verificar potenciales afectaciones del bien jurídico, aunque sean de escasa entidad, de manera que la mayoría de comportamientos deberán reputarse atípicos, no en virtud del principio de insignificancia, sino por su objetiva inadecuación ex ante para poner en peligro el objeto jurídico del delito.

Por otro lado, en el plano de la técnica legislativa empleada, se tratará de constatar como el elevado grado de abstracción inherente a la definición legal de algunos de los elementos

10 Vid. Alć́cer Guirao, R.: "Facticidad y normatividad. Notas sobre la relación entre ciencias sociales y Derecho penal", en Anuario de Derecho Penal y Ciencias Penales, Vol. LII, 1999, pp. 182 y ss.

11 Explica cómo, desde la perspectiva de la intervención en derechos fundamentales, mediante la definición del tipo penal se produce una restricción de posiciones de libertad, Lopera Mesa, G. P.: Principio de proporcionalidad y ley penal, Madrid, 2006, pp. 278 y ss. 
conformadores de la descripción típica podría ser contraria al principio de legalidad en su manifestación relativa a la garantía de taxatividad de la ley penal ${ }^{12}$. En concreto, la referencia genérica en el tenor literal del tipo al concepto de violencia como atributo del alzamiento público, sin explicitar las clases de la misma específicamente incriminadas, podría dificultar el acceso cognitivo al imperativo de conducta contenido en la norma primaria. Ello podría implicar una ampliación de los márgenes de arbitrio judicial hasta extremos incompatibles con los postulados de un Estado democrático por suponer una usurpación de funciones propias del poder legislativo, esto es, del órgano en el que reside la auténtica soberanía popular según el pensamiento de raíz liberal inspirador del régimen jurídico-político vigente ${ }^{13}$. Según ello, el legislador debería establecer las expresiones de violencia concretamente incriminadas a fin de poder conocer cuáles son los referentes empíricos subyacentes a ella.

Desde una perspectiva histórica, en la tradición española el delito de rebelión adquiere una especial proyección al haber correspondido en múltiples períodos de la misma a la autoridad militar la facultad de decidir cuándo se dan los presupuestos jurídicos necesarios para tener atribuida la misión de salvaguardar la seguridad interior del Estado, en cuyo caso sus bandos se convertían en ley preferente ${ }^{14}$. Así pues, no por casualidad en el antecedente judicial más inmediato de esta figura delictiva, relativo al golpe de Estado fallido de 23 de febrero de 1981 (STS de 22 de abril de 1983), el teniente general Milans del Bosch in-

12 Musco, E.: "La irracionalidad en el Derecho penal", en Revista Electrónica de Ciencia Penal y Criminología, $\mathrm{n}^{\circ} 16-1,2014$, pp. 8 y 9.

13 Vid. DAHL, R.: La democracia y sus críticos, Barcelona / Buenos Aires, 1992, p. 41.

14 La declaración del estado de guerra llevaba consigo la publicación de un catálogo de comportamientos considerados rebeldes. En atención a la gran cantidad de bandos declaratorios del mismo, en España históricamente ha existido un auténtico archipiélago de conductas "rebeldes", como explica García Rivas, N.: “¿Rebelión en Cataluña? La Fiscalía de la Audiencia Nacional persigue 'sombras rebeldes", en Eunomía, n 10, 2016, p. 92. 
vocó esa potestad, procedente de las Reales Ordenanzas de Carlos III de 1768 y con reminiscencias del Antiguo Régimen, para dictar un bando declarando la ilegalidad de partidos políticos y sindicatos. Afortunadamente, en el marco jurídico actual esta opción queda totalmente descartada al suprimirse la "autonomía militar" 15 en virtud del art. 1.2 CE, mediante el que se proclama la "soberanía popular", y del art. $116 \mathrm{CE}$, en el que se atribuye al Gobierno la competencia para declarar los estados de alarma y de excepción y al Congreso de los Diputados el estado de sitio.

Sentado lo anterior, cualquier esfuerzo que tenga como objetivo dotar de mayor concreción al alzamiento rebelde resulta loable al contribuir, con mayor o menor acierto, a satisfacer las exigencias derivadas de los principios de legalidad y lesividad. En lo sucesivo se tratará de corroborar que el art. $472 \mathrm{CP}$ designa, al mismo tiempo, las conductas constitutivas del delito de rebelión y las condiciones fácticas que han de darse para declarar el estado de sitio. Bajo esta perspectiva, la rebelión típica debe suponer una puesta en peligro de la estructura básica del Estado de tal entidad que obligue a utilizar el último recurso del que dispone el poder estatal dentro del monopolio de la violencia legítima que ejerce: la fuerza del Ejército ${ }^{16}$.

\section{Bien jurídico protegido}

El bien jurídico protegido por el delito de rebelión es de carácter supraindividual, por lo que en cierta medida dispone

15 La "autonomía militar" se eliminó por primera vez a través de la Ley de Orden Público de 1933. Dado que a partir de entonces el estado de guerra sólo podía ser declarado por el Gobierno legítimo, los bandos emitidos por el general Franco serían nulos de pleno derecho, como advierte GARCía RIVAS, N.: “¿Rebelión en Cataluña? La Fiscalía de la Audiencia Nacional persigue 'sombras rebeldes"', en Eunomía, n 10, 2016, p. 93.

16 A favor de que sólo es idónea desde la óptica del delito de rebelión la conducta capaz de crear una crisis constitucional de tal magnitud que su solución pase indefectiblemente por la intervención de las Fuerzas Armadas, Sandoval, J. C.: El delito de rebelión. Bien jurídico y conducta típica, Valencia, 2013, pp. 393-394. 
de contornos difusos, con el consiguiente riesgo de desvanecimiento de su sustrato material a través de imbricados procesos de normativización de su contenido ${ }^{17}$. Aunque la creación del título XXI dedicado a los "delitos contra la Constitución", entre los que se sitúa el delito de rebelión, supuso una de las novedades más reseñables y celebradas del CP de 1995, motivando incluso la calificación del mismo como el "Código penal de la Democracia", lo cierto es que con esta manifestación delictiva no se tutela una suerte de deber de fidelidad del súbdito hacía las disposiciones superiores del Ordenamiento jurídico (Constitución en sentido formal), sino los derechos fundamentales y libertades públicas que éstas proclaman (Constitución en sentido material) ${ }^{18}$. Desde este punto de vista, el término "Constitución" en la rúbrica del título XXI aludiría a la tutela de aspectos esenciales del sistema jurídico-político e institucional diseñado por el Texto Fundamental. De ello se extrae una primera conclusión según la que uno de los parámetros para evaluar la carga de ofensividad de la conducta sería el daño potencial que ésta origina en las posibilidades de autorrealización personal amparadas por la Constitución. Desde esta perspectiva, el comportamiento típico debe atentar contra las bases del sistema de convivencia concretadas en la carta de derechos contenida en el art. 10.1 $\mathrm{CE}$ que, como manifestaciones del principio de dignidad de la

17 Sobre las características del bien jurídico protegido por el delito de rebelión, García Rivas, N.: Lecciones y materiales para el estudio del Derecho penal, Madrid, 2016, pp. 229 y ss.

18 Estima que los fines caracterizadores del alzamiento propio del delito de rebelión van más allá de la derogación de la Constitución, al incluir manifestaciones violentas contra determinadas medidas gubernamentales o legislativas (p.ej. la convocatoria de elecciones), García RIVAS, N.: Lecciones y materiales para el estudio del Derecho penal, Madrid, 2016, p. 230. En mi opinión, por razones materiales relativas a los principios de lesividad y proporcionalidad, estos otros ataques tan sólo pueden ser relevantes desde la óptica de la rebelión cuando, justamente, son capaces de atentar contra los aspectos más nucleares de la Constitución al condicionar la configuración democrática del régimen jurídico-político que ésta establece. 
persona, conforman el fundamento de la paz social y del orden político vigente ${ }^{19}$.

El título XXI comprende el grueso del denominado Derecho penal político respecto el modelo de organización política del Estado democrático, en concreto, en lo concerniente a las relaciones de éste con los ciudadanos ${ }^{20}$. Esta ubicación sistemática del delito de rebelión no es un detalle menor puesto que sólo los Códigos de 1870 y 1995 han incluido en sus respectivos articulados un título específico destinado a la protección del sistema social establecido en la Carta Magna ${ }^{21}$. Según ello, el objeto de tutela del delito de rebelión no podría cifrarse en la realización y mantenimiento de todos los principios consagrados en la Constitución de 1978, sino sólo de aquellos más esenciales desde una óptica individual, como son los de libertad, justicia, igualdad, pluralismo político, respeto a la dignidad de la persona, respeto a la Ley o libre desarrollo de la personalidad. Así pues, para la comisión de un delito de rebelión no bastaría con la infracción de cualquier precepto legal de rango constitucional, sino que sería necesaria una perturbación del núcleo del sistema democrático a través de la puesta en peligro de alguno de los derechos fundamentales que integran su parte más sustancial ${ }^{22}$.

19 En esta misma línea, García Rivas, N.: La rebelión militar en Derecho Penal, Albacete, 1990, pp. 137 y ss., considera que con el delito de rebelión se protege el orden constitucional democrático, de manera que la conducta debe ser adecuada para poner en crisis el proyecto político configurado por la norma fundamental.

20 Sobre como el Derecho penal político comprende parte de la protección penal de la que el Estado se dota a sí mismo, Muñoz Conde, F.: Derecho penal. Parte especial, Valencia, 2017, pp. 784 y ss. Sobre el concepto de delito político, Sandoval, J. C.: El delito de rebelión. Bien jurídico y conducta típica, Valencia, 2013, pp. 398 y ss.

21 Explica como el intento de golpe de Estado del 23 de febrero de 1981 motivó una reforma del delito de rebelión a través de la LO 2/1981, de 4 de mayo, en virtud de la que esta infracción empezó a concebirse como un delito contra la Constitución, más allá de sus efectos sobre el orden público, Muñoz Conde, F.: Derecho penal. Parte especial, Valencia, 2017, p. 785.

22 Sobre como el término "alzarse" equivale a levantarse, esto es, a romper la relación de sumisión a las leyes y autoridades legítimas, Vives ANTón / 
En opinión de un sector de la doctrina, el delito de rebelión no sólo tutela los principios y valores esenciales del sistema constitucional, al existir una zona de protección compartida con el delito de sedición, consistente en la paz pública entendida como algo más básico y esencial que el orden público, esto es, como la parte de la organización democrática del Estado concretada en el interés de éste en la sumisión general de los ciudadanos a la Constitución, a las leyes y a las autoridades legítimas ${ }^{23}$. Sin embargo, esta visión del delito de rebelión resulta discutible en una concepción no formal de su injusto ya que en ella la voluntad del Estado de obtener la sumisión de los ciudadanos al Ordenamiento jurídico no se protege en su dimensión de deber de obediencia a una determinada orden o pretensión de la autoridad al margen de su contenido, sino en su dimensión material como expresión de la necesidad de garantizar la indemnidad de los derechos fundamentales plasmados en el texto constitucional ${ }^{24}$.

Desde este punto de vista, el principio de autoridad, si sólo se tutela como presupuesto de la vigencia y eficacia de los valores inherentes a un Estado social y democrático de Derecho, carecería de autonomía como bien jurídico. Esta orientación del valor protegido sería coherente con la intención del legislador de 1995 de cambiar el enfoque político-criminal del delito en estudio para eliminar los rasgos autoritarios que lo habían ca-

Carbonell Mateu, "Delitos contra la Constitución", en Derecho Penal. Parte Especial, Ed. Tirant lo Blanch, Valencia, 2004, p. 984.

23 Sobre la consideración de la figura de la rebelión como un delito contra la seguridad interior del Estado, Ganzenmüller Roig, C. / Escudero Moratalla, J. R. / Frigola Vallina, J.: Delitos contra la Administración Pública; contra la Administración de Justicia, y contra la Constitución, Barcelona, 1998, pp. 271 y ss. Según exponen los autores, el delito de rebelión, aunque se mueva dentro del marco formal de la seguridad interior del Estado, protege la normal y efectiva aplicación de la Constitución, esto es, del aparato de poder que en la misma se establece.

24 En este sentido, como significa García Rivas, N.: La rebelión militar en Derecho Penal, Albacete, 1990, pp. 137 y ss., el delito de rebelión se dirige a la salvaguarda de la Constitución misma, es decir, a la garantía de la realización del proyecto político asentado por la norma fundamental. 
racterizado en el pasado, cuando el objeto prioritario de tutela era un supuesto deber de lealtad del súbdito hacia el Estado ${ }^{25}$. Así pues, desde este prisma las concomitancias entre los intereses protegidos por el delito de rebelión y el de sedición se limitan a la prevención en ambos de alteraciones graves del normal funcionamiento de las instituciones. Ahora bien, en el delito de rebelión las alteraciones del normal funcionamiento de las instituciones que se tratan de prevenir son todavía más graves al referirse a atentados que impliquen una amenaza para la subsistencia del orden constitucional ${ }^{26}$.

El encabezamiento que el delito de rebelión del art. 472 $\mathrm{CP}$ realiza de los delitos contra la Constitución sugiere la configuración de esta figura como máximo atentado contra el sistema constitucional. Esta posición sistemática además lo aleja definitivamente de los delitos contra el orden público, entre los que se cuenta el delito de sedición, con lo que históricamente ha guardado notables similitudes ${ }^{27}$. De este modo resalta la especial gravedad del alzamiento en el delito de rebelión, como levantamiento público consistente en un ataque organizado que suponga un enfrentamiento con el poder constituido para lograr su derrocamiento ${ }^{28}$. Ello determina que en el momento de actuar el levantamiento público y violento deba ser objetivamente adecuado para deponer, suprimir o modificar la forma de gobierno o

25 Sobre el proceso de saludable depuración de los tipos contra la Constitución incluidos en el Título XXI, a los efectos de eliminar o corregir los que eran incompatibles con las libertades públicas de un Estado democrático, GARCíA Rivas, N.: Lecciones y materiales para el estudio del Derecho penal, Madrid, 2016, pp. 227 y ss.

26 En esta misma línea, AAN de 21 de diciembre de 2015.

27 Cuestiona la actual ubicación sistemática del delito de rebelión entre los delitos contra la Constitución, Morillas Cueva, L.: Sistema de Derecho penal. Parte especial, Madrid, 2016, pp. 1248 y ss.

28 Según indica González Rus, J.J.: Sistema de Derecho penal español. Parte especial, Madrid, 2011, p. 1066, los supuestos legales del delito de rebelión detallan situaciones que aislada o conjuntamente consideradas suponen acabar o subvertir los fundamentos básicos del sistema democrático constitucional. 
el régimen constitucional al margen de los procedimientos legales establecidos para ello ${ }^{29}$.

El rigor punitivo del delito de rebelión se explica por su tradicional configuración como infracción de naturaleza eminentemente militar. Desde esta perspectiva, la evolución de esta manifestación delictiva puede contemplarse como una reacción a los sucesivos pronunciamientos militares, a través de los correspondientes golpes de Estado, que mediatizaron buena parte de la vida política española en los siglos XIX y XX ${ }^{30}$. Ello no significa que este delito se estructure como un tipo especial sólo susceptible de ser cometido por miembros de las Fuerzas Armadas, al ser perfectamente imaginable una rebelión típica de carácter no militar, pero sí que la conducta ha de generar una especial conmoción sobre aspectos nucleares del sistema de convivencia social previsto en la Constitución.

Desde la lógica del discurso liberal que inspira nuestro Ordenamiento, la existencia del delito de rebelión está justificada porque la "seguridad" del Estado democrático se identifica con la "seguridad" del ordenamiento constitucional y del sistema de relaciones entre el Estado y los ciudadanos que en él se contienen. Ahora bien, si las instituciones estatales no son algo independiente de los valores y principios políticos que las sustentan, la protección de las mismas no es un fin en sí mismo, sino que sólo tiene sentido en tanto que contribuyen a la efectividad del marco político-jurídico de libertades en el que se inscriben.

29 Vid. ReÁtegul SÁnchez, J.: "Los límites de la conducta típica en la rebelión ¿Es un delito de los 'derrotados' o de los 'triunfadores'?”, en Itaius esto, $\mathrm{n}^{\circ}$ 1,2008 , pp. 3 y ss.

30 Según indica la historiografía, las rebeliones militares en España acostumbran a seguir patrones parecidos. Una vez iniciadas, se publicitan mediante la proclamación de bandos de declaración del estado de guerra, en los que los dirigentes rebeldes, poniéndose al margen y en contra de las autoridades legítimas, anuncian que se adueñan de los poderes del Estado, sustituyendo $\mathrm{o}$, al menos, dejando en suspenso, a los que hasta entonces los ejercían legítimamente, para lo que crean una especie de consejo que denominan Junta de Defensa Nacional. Vid. Sánchez Recio, G.: Aniquilación de la República y castigo a la lealtad, Alicante, 2015, pp. 107 y ss. 
Sentado lo anterior, cabe concluir que con el delito de rebelión se protegen los aspectos nucleares de la Constitución sintetizados en su art. 1, concretados a través de los preceptos subsiguientes. Según ello, la conducta típica debe afectar a los fundamentos ideológicos de la Constitución inherentes a un Estado social y democrático de Derecho, por lo que, al margen de si se menoscaba la organización jurídico-política del Estado o su estructura socioeconómica, deben atacarse valores superiores del Ordenamiento como la justicia, la igualdad, la libertad o el pluralismo político ${ }^{31}$. Por consiguiente, no sólo se tutela el orden constitucional en cuanto tal, sino el proyecto político que éste configura y representa, lo que obliga a ser especialmente exigentes en cuanto al mínimo grado de lesividad de la conducta prohibida por este delito.

Bajo esta perspectiva, el delito de rebelión se articularía como un tipo pluriofensivo en el que se lesionaría el orden público y se colocaría en una situación de abstracto peligro el orden constitucional democrático. Según ello, el factor vertebrador del tipo sería el peligro para las instituciones o valores que aparecen descritos en los fines del mismo, en su proyección de elementos conformadores de la organización territorial del Estado. Si no se produce ese grave peligro para la Carta Fundamental, es decir, para el conjunto del ordenamiento constitucional democrático, la realización de alguna conducta descrita en el tipo como fin rebelde a lo sumo podría ser constitutiva de algún otro delito, al margen de los objetivos perseguidos por los autores ${ }^{32}$.

31 En opinión de García Rivas, N.: Lecciones y materiales para el estudio del Derecho penal, Madrid, 2016, p. 231, "no bastaría con que un grupo de cientos de personas se manifiesten con violencia para reivindicar, por ejemplo, la independencia de una parte del territorio nacional, si dicho 'alzamiento' no representa un peligro para el sistema constitucional vigente".

32 Vid. González Rus, J.J.: Sistema de Derecho penal español. Parte especial, Madrid, 2011, p. 1066 y ss. 


\section{Naturaleza jurídica}

La conducta típica del delito de rebelión consiste en "alzarse" de forma pública y violenta para la consecución de alguna de las siete finalidades previstas en el tipo: derogar, suspender o modificar total o parcialmente la Constitución; destituir o despojar en todo o en parte de sus prerrogativas o facultades al Rey o Reina o al Regente o miembros de la Regencia, u obligarles a ejecutar un acto contrario a su voluntad; impedir la libre celebración de elecciones para cargos públicos; disolver las Cortes Generales, el Congreso de los Diputados, el Sentado o cualquier Asamblea Legislativa de una Comunidad Autónoma, impedir que se reúnan, deliberen o resuelvan, arrancarles alguna resolución o sustraerles alguna de sus atribuciones o competencias; declarar la independencia de una parte del territorio nacional; sustituir por otro el Gobierno de la Nación o el Consejo de Gobierno de una Comunidad Autónoma, o usar o ejercer por sí o despojar al Gobierno o Consejo de Gobierno de una Comunidad Autónoma, o a cualquiera de sus miembros de sus facultades, o impedirles o coartarles su libre ejercicio, u obligar a cualquiera de ellos a ejecutar actos contrarios a su voluntad; o sustraer cualquier clase de fuerza armada a la obediencia del Gobierno.

Tiene carácter público el alzamiento manifiesto, sabido o conocido por todos, por lo que ha de ser patente, notorio y no oculto o disimulado, de modo que los rebeldes han de expresar declaradamente, a través de actos concluyentes, su abierta hostilidad, sea o no de forma verbal o expresa. En consecuencia, la publicidad es una de las exigencias del tipo, aunque, al ser intrínseca a la noción de alzamiento, el adjetivo "público" podría eliminarse del tenor literal del tipo sin mayores problemas. La notoriedad requerida implica que los autores deben poner de manifiesto, de forma simultánea y con la misma intensidad, dos elementos concretos del alzamiento: en primer lugar, la finalidad última de atentar contra el orden constitucional democrático especificado a través de los distintos fines previstos en el tipo; $y$, en segundo lugar, la idoneidad de la conducta para materializar la intención de los alzados. De esta manera la exigencia de 
publicidad serviría para marcar la frontera entre la rebelión punible y la mera disidencia política no exteriorizada.

En atención a que la conducta típica no tiene que ir seguida de un resultado separable espacio-temporalmente de la misma, el delito de rebelión integra un tipo de mera actividad. Asimismo, dado que la consumación delictiva se produce sin necesidad de materialización efectiva de ninguno de los mencionados fines, al bastar con la objetiva adecuación de la conducta para alcanzarlos en el momento de realizarse, el delito en estudio se configura como un tipo de peligro abstracto. Ahora bien, esta circunstancia no lo convierte en una infracción meramente formal, en un simple ilícito de desobediencia, de modo que la conducta individualmente considerada ha de ser potencialmente capaz de subvertir el orden político establecido. En concreto, ha de tratarse de una rebelión contra las autoridades constituidas objetivamente idónea para derrocar el Gobierno legítimo ${ }^{33}$, es decir, para situar la vigencia y efectividad de los aspectos más esenciales de la Constitución en una zona de incertidumbre penalmente relevante. Según ello, la rebelión típica se articularía como un delito de consumación anticipada, en la modalidad de delito de resultado cortado, por cuanto el perfeccionamiento delictivo no dependería de la verificación en un plano objetivo del propósito último de los agentes.

Este adelantamiento de las barreras de protección obedece a razones lógicas puesto que, al aspirar los insurgentes a la subversión del orden constitucional, el triunfo de la rebelión comporta la imposibilidad de juzgarlos con arreglo al orden institucional depuesto. Según ello, carece de sentido situar el momento consumativo en una fase de la insurrección en la que el

33 En la misma dirección, STS de 22 de abril de 1983; de 3 de junio de 1989. Según reseñan Vives Antón / CARbonell Mateu, “Delitos contra....", p. 984, el alzamiento público y violento ha de perseguir subjetivamente alguna de las finalidades descritas en el precepto. Sólo de este modo podría estimarse que se quebranta la legalidad con violencia y, por lo tanto, fuera de los cauces legales posibles. 
Derecho penal vigente ya no podría desplegar eficacia alguna. La anticipación de las barreras de protección a través de la estructuración del delito de rebelión como un delito de peligro abstracto, unida a la expresa incriminación de determinados actos preparatorios en el art. $477 \mathrm{CP}$, prácticamente no deja espacio para la apreciación de tentativa y obstruye además la labor de distinción entre los actos preparatorios y los ejecutivos.

Desde otro punto de vista, se trata de un delito plurisubjetivo de convergencia por cuanto requiere de una unión o concierto de voluntades para la consecución de un propósito común ${ }^{34}$. Ahora bien, es indiferente la cantidad de personas que se rebelen, de manera que lo determinante es que sea en número suficiente para la consecución de los fines fijados en el tipo. De acuerdo con esta naturaleza de tipo pluripersonal de ejecución colectiva, cabe descartar la perpetración del delito por parte de una única persona. Un sector de la doctrina agrega al carácter pluripersonal del delito la exigencia de un mínimo de organización entre los intervinientes en el alzamiento. Sin embargo, lo verdaderamente relevante es, al margen de si los rebeldes están más o menos organizados, la objetiva idoneidad del comportamiento para lograr los fines previstos en el tipo como medio para la destrucción de principios esenciales del orden constitucional ${ }^{35}$.

34 El número de personas que integran la rebelión es indiferente, si bien debe ser suficiente para la consecución de los fines determinados por el tipo. Por este motivo, el delito de rebelión se califica de delito plurisubjetivo de conductas que convergen, en el que los sujetos llevan a cabo un alzamiento público y violento contra el poder legalmente constituido. Vid. GANZENMÜLLER Roig, C. / Escudero Moratalla, J. R. / Frigola Vallina, J.: Delitos contra la Administración Pública; contra la Administración de Justicia, y contra la Constitución, Barcelona, 1998, p. 274.

En el mismo sentido, Vives Antón / Carbonell Mateu, "Delitos contra...", p. 984, indican que las voluntades de los múltiples autores confluyen en un fin común.

35 Es necesaria, en esencia, una conducta dinámica activa dirigida a la consecución de alguno o varios de los fines descritos en los siete números que contempla el precepto, vinculados todos ellos a una voluntad manifiesta de repudiar el sistema político. Vid. Ganzenmüller Roig, C. / Escudero 
No basta con que los rebeldes actúen con el ánimo de conseguir alguno de estos objetivos, ni con la voluntad de subvertir los aspectos más nucleares del régimen constitucional, es decir, de menoscabar gravemente el sistema de derechos fundamentales y libertades públicas consagrado por la Carta Magna, sino que su conducta debe ser en el momento de emprenderse objetivamente adecuada para ocasionar estos efectos. Así pues, la rebelión debe comportar una amenaza grave para la continuidad del modelo de convivencia propio de un Estado social y democrático de Derecho.

De ser la rebelión adecuada para la realización de alguna de las finalidades típicas, pero carecer de la entidad necesaria como para comprometer la existencia de alguna de las características inherentes al paradigma político-jurídico vigente, el hecho debería alojarse en otras tipologías delictivas. Por ejemplo, en caso de impedirse la reunión o deliberación de los miembros de la Asamblea Legislativa de una Comunidad Autónoma, la conducta es atípica desde la óptica del delito de rebelión si la obstrucción de esta función de este órgano no menoscaba gravemente alguno de los aspectos concretos sobre los que se cimienta el régimen constitucional, por más que se realice uno de los fines previstos en el art. $472 \mathrm{CP}$ consistente en impedir el ejercicio o normal desarrollo de alguna de las atribuciones o competencias propias de esta cámara legislativa ${ }^{36}$. Desde esta perspectiva, la

Moratalla, J. R. / Frigola Vallina, J.: Delitos contra la Administración Pública; contra la Administración de Justicia, y contra la Constitución, Barcelona, 1998, p. 274.

36 En un plano axiológico, las rebeliones militares se intentan justificar con el recurso al concepto de tiranicidio, según el que existiría un derecho a derrocar un gobierno tiránico y gravemente perjudicial para la sociedad, por medios legales si es posible y, si no lo es, a través de un alzamiento armado. Desde esta perspectiva, el cardenal Gomá, en una carta firmada por casi todos los prelados, afirmó que el alzamiento de 1936 fue un "plebiscito armado". Asumiendo este planteamiento, a comienzos de 1939, los autores del dictamen de la Comisión sobre la ilegitimidad de los poderes actuantes el 18 de julio de 1936, nombrada mediante orden del Ministerio de Gobernación de 21 de diciembre de 1938, concluyeron que "el Glorioso Alzamiento 
atipicidad del comportamiento respecto el delito de rebelión podría venir motivada por la inidoneidad de la misma para amenazar la pervivencia de la Constitución en cuanto tal ${ }^{37}$.

Para castigar conductas perturbadoras del funcionamiento ordinario de las más altas instituciones del Estado, sin llegar a generar un riesgo de abolición de la Constitución pese a atacarse el orden político previsto en ella, existen otras tipologías delictivas dentro del mismo título XXI del Código penal. Así las cosas, una conducta como la descrita en el ejemplo podría acomodarse en el art. 498 CP, a través del que se sanciona el empleo de fuerza, violencia o intimidación para impedir a un miembro del Congreso de los Diputados, del Senado o de una Asamblea Legislativa de Comunidad Autónoma asistir a sus reuniones, o, por los mismos medios, los intentos de cortar la libre manifestación de sus opiniones o la emisión de su voto ${ }^{38}$. Este delito tiene carácter pluriofensivo al proteger, no sólo la simple libertad u honorabilidad de los miembros de las referidas cámaras, sino también el derecho de participación política de los ciudadanos reconocido en el art. $23 \mathrm{CE}$. Consecuentemente, podrían subsumirse en este delito perturbaciones del normal funcionamiento de los órganos parlamentarios que, sin ser adecuadas para cambiar el marco de relaciones jurídico-políticas, puedan vaciar de contenido determinados derechos fundamentales, al afectar, de forma directa, al derecho del

Nacional no puede ser calificado en ningún caso de rebeldía, en el sentido jurídico-penal de esta palabra, representando, por el contrario, una suprema apelación a los resortes legales de fuerza que encerraban el medio único de restablecer la moral y el derecho, desconocidos y con reiteración violados". Se trata de procesos que los historiadores denominan de mistificación de la rebelión. Con mayor detalle, SÁnchez Recio, G.: Aniquilación de la República y castigo a la lealtad, Alicante, 2015, pp. 110 y ss.

37 Terminada la guerra civil, los vencedores utilizaron el delito de rebelión para castigar la lealtad de los republicanos, como ilustra la represión contra los jueces del Tribunal Supremo, el Tribunal Popular de Albacete y el Tribunal Militar Permanente del II Cuerpo del Ejército del Centro. Sobre ello, vid. SÁnchez Recio, G.: Aniquilación de la República y castigo a la lealtad, Alicante, 2015, pp. 112 y ss.

38 En la misma dirección, STS 161/2015, de 17 de marzo. 
diputado electo al ejercicio del cargo público para el que fue designado y, de modo indirecto, al derecho de todos los ciudadanos a participar en los asuntos públicos mediante sus representantes.

Según se ha expuesto, en el delito de rebelión, pese a su naturaleza de tipo penal de mera actividad y de peligro abstracto, en cada caso hay que comprobar individualmente la objetiva idoneidad del comportamiento para lesionar el interés tutelado. Sólo de esta manera el injusto de esta figura delictiva puede disponer de una carga lesividad suficiente como para justificar el merecimiento de pena del hecho desde una óptica material. Sólo a través de esta interpretación restrictiva del delito de rebelión, según la que la conducta debe ser capaz de provocar una grave crisis constitucional, como ocurre de forma paradigmática con los levantamientos militares, es posible afirmar que este tipo penal no se dirige a la mera tutela de la lealtad de los ciudadanos hacia el sistema jurídico. Asimismo, no basta con la perpetración de un atentado contra la más elevada norma del Ordenamiento fuera de los cauces legales, sino que la actuación debe dirigirse contra el propio Estado de forma violenta. De no revestir carácter violento, la rebelión no pude integrar un alzamiento típico desde el prisma del art. $472 \mathrm{CP}^{39}$.

Sentado lo anterior, el delito de rebelión se configura, desde la perspectiva de los sujetos activos, como un delito común al no exigir los preceptos que lo regulan ningún tipo de cualidad o condición personal en ellos. También desde el punto de vista de los sujetos activos, el delito de rebelión se articula como un tipo pluripersonal al describir conductas que sólo pueden ser realizadas por varios agentes. En consecuencia, no puede existir una rebelión típica individual de una sola persona, si bien no es necesaria una organización entre los sujetos activos previa

39 Como corrobora el posicionamiento de Manzanares Samaniego, J. L.: "El Código Penal en el proceso independentista de Cataluña”, en Diario La Ley, $\mathrm{n}^{\circ}$ 9061, 2017, pp. 1 y ss., quien pese a oponerse políticamente a los fines del proceso independentista, aboga por la atipicidad de los actos que lo han compuesto desde la óptica del delito de rebelión. 
al alzamiento.

Por otro lado, la consumación delictiva no coincide con la efectiva lesión del bien jurídico al no exigir el legislador que el alzamiento destruya o altere efectivamente el ordenamiento constitucional democrático, de modo que basta con la realización de actos tendentes a ocasionar este resultado. Así pues, en el delito de rebelión se produce la anticipación de la consumación propia de los delitos de peligro abstracto. Asimismo, la consideración de este delito como un tipo de mera actividad determina la inexistencia de problemas en cuanto a la (ausente) relación de causalidad entre conducta y resultado.

\section{Estructura típica. Diferencias con el delito de sedición (art. 544 CP)}

Según se ha expuesto, el delito de rebelión se configura como una insurrección tendencialmente encaminada a lesionar el Ordenamiento constitucional, a través del ataque a instituciones fundamentales del sistema político como son la Corona o el Gobierno. El verbo rector del tipo, consistente en "alzarse", podría conceptualizarse como un "levantamiento", "sublevación" o "insurrección" contra las autoridades legítimas. Según ello, el término alzamiento implicaría un acto de insumisión o insubordinación para romper la relación de sumisión a las leyes. Un sector de la doctrina agrega que en el alzamiento se falta a la obediencia debida al existir una actitud de "desobediencia" o "resistencia" de carácter colectivo ${ }^{40}$. Sin embargo, esta identificación de la rebelión con la desobediencia o la resistencia podría inducir a confusión, toda vez que podría sugerir la necesidad de una orden previa de la autoridad como presupuesto para la tipicidad de la conducta ${ }^{41}$.

40 Analiza críticamente esta postura, Sandoval, J. C.: El delito de rebelión. Bien jurídico y conducta típica, Valencia, 2013, pp. 300 y ss.

41 Con el paso del tiempo el denominado "proceso independentista catalán" cada vez ha ido adquiriendo, sin duda, una mayor dimensión internacional 
Con la voluntad de restringir el alcance del tipo, las sucesivas reformas del delito han concretado las características que debe presentar el alzamiento. En 1981 se introdujo el adverbio "públicamente", en el sentido de que la insurrección frente a la autoridad legítima sea notoria o manifiesta. De este modo el carácter público del comportamiento pasó a ser la nota común entre los delitos de rebelión y sedición los cuales incriminan, respectivamente, el "alzamiento violento" y el "alzamiento tumultuario"42. El requisito de la violencia en el alzamiento de

fomentada, al menos en parte, por la petición de entrega de los Tribunales españoles a terceros países de algunos de los procesados por rebelión fugados. Esta situación ha derivado en un intenso debate acerca de la doble incriminación como requisito de la entrega. En esta línea, el Tribunal Superior de Schleswig-Holstein denegó la solicitud de entrega del ex presidente de la Generalitat de Catalunya por el delito de rebelión al estimar que faltaba el requisito de la doble incriminación "en concreto", es decir, por no ser en Alemania los hechos investigados constitutivos de esta infracción. Sobre ello, Javato Martín, A.: "¿Existe el delito de sedición en Alemania, Suiza y Bélgica?", en Diario La Ley, no 9188, 2018, pp. 1 y ss.

Al margen de si estos hechos específicos serían o no constitutivos de un delito de rebelión en otros países, lo cierto es que en muchos de ellos existen tipos penales que castigan con elevadas penas los intentos de poner en peligro la existencia del Estado de que se trate con violencia física o intimidación. A título de ejemplo, el art. 81 del CP alemán prevé una infracción similar a la rebelión, llamada delito "de alta traición", con penas que pueden llegar a la cadena perpetua, para el que a través de la violencia física o de la amenaza de uso de la misma intente perjudicar la existencia de la República Federal de Alemania o cambiar el orden constitucional en el que ésta se basa. Por su parte, el CP belga prevé distintos delitos para perseguir complots contra el Rey o la forma de Gobierno en los arts. 101 a 112, así como el llamado delito de "coalición de funcionarios" de los arts. 233 a 236, enmarcado dentro de los delitos contra el orden público, según el que varios funcionarios se organizarían como un grupo criminal con la finalidad de delinquir. Asimismo, el art. 411 del CP francés tipifica, con penas que pueden llegar hasta los 30 años de prisión, la comisión de uno o varios actos de violencia susceptibles de poner en peligro las instituciones de la República o de atentar contra la integridad del territorio nacional.

42 Como señalan Vives Antón / CARbonell Mateu, "Delitos contra el orden público", en Derecho Penal. Parte Especial, Ed. Tirant lo Blanch, Valencia, 2004, p. 1024, el delito de sedición exige que el alzamiento tenga lugar "tumultuariamente", es decir, a través de un "alboroto producido por una muchedumbre" que origine la consiguiente conmoción en el orden público. 
la rebelión se añadió con la promulgación del Código penal de $1995^{43}$. Con esta exigencia se trató de satisfacer las demandas de los partidos políticos independentistas que, en el curso del debate parlamentario anterior a la aprobación de la Ley, se opusieron a la posibilidad de contemplar como una hipótesis de rebelión típica una eventual declaración de independencia procedente de una cámara legislativa autonómica realizada de manera pacífica, pero al margen de los procedimientos legalmente establecidos para la reforma de la Constitución ${ }^{44}$.

Así pues, a la luz de la discusión parlamentaria que la precedió, la decisión de adjetivar el "alzamiento" como "violento" respondió a la voluntad de evitar un posible uso autoritario del delito de rebelión. Ahora bien, ello no debe ocultar el importante grado de imprecisión en lo que respecta al alcance del concepto de violencia, lo que indica que la decisión del legislador de exigirla no estuvo acompañada de una reflexión serena sobre el significado del término en el ámbito de la figura en estudio, esto es, sobre si el mismo ha de ser más o menos amplio.

En atención al carácter violento del alzamiento, para la existencia de un delito de rebelión no basta con la persecución de alguno de los fines previstos en el tipo fuera de las vías legales, ni con una ilegítima alteración del orden constitucional,

43 Sobre como la exigencia de que el alzamiento rebelde sea violento es una constante en Derecho comparado, sobre todo en países de nuestro entorno cultural de referencia como Alemania, Suiza, Portugal o Italia, Manzanares SAmaniego, J. L.: "El Código Penal en el proceso independentista de Cataluña”, en Diario La Ley, n 9061, 2017, pp. 1 y ss.

44 Como se señala en el AAN de 8 de febrero de 2016, a propósito de la aprobación de mociones municipales en apoyo a la resolución 1/XI del Parlament de Catalunya, de 3 de noviembre de 2015, en el campo penal no es posible equiparar los alzamientos violentos, desordenados u hostiles, con los actos ilegales e inconstitucionales realizados en sede parlamentaria y que no han trascendido de ese ámbito, aunque sea con publicidad: "como se ha dicho, la rebelión exige el empleo de la fuerza y el bien jurídico protegido en el delito de sedición es el 'orden público' que no nos consta alterado por los hechos". 
sino que ésta debe producirse de forma violenta ${ }^{45}$. La atipicidad de los golpes de Estado por cauces pacíficos desde la óptica del delito de rebelión, sin perjuicio de que la conducta pueda ser constitutiva de otros tipos penales, es la opción más acorde con un sistema basado en el pluralismo político ${ }^{46}$.

Ahora bien, aún queda por examinar el alcance de la noción de violencia en este delito, en el sentido de dilucidar si ésta sólo abarca actos de fuerza física realizados sobre las personas ("vis física") o también la intimidación como amenaza de usar la fuerza física ("vis psíquica") ${ }^{47}$. De estimarse que el legislador ha tipificado ambas clases de violencia, se castigaría el alzamiento en el que se recurre a la fuerza física y en el que el empleo de ésta se presenta como una posibilidad seria y fundada al haber exteriorizado los alzados, de forma pública y patente, su intención de conseguir los fines propuestos por cualquier medio $^{48}$. Según ello, únicamente no sería necesaria la efectiva concurrencia de violencia física cuando por las características del alzamiento -por la cantidad de personas implicadas, por el grado de organización existente entre ellas, por su cargo, por los medios de los que disponen, etc.- pueda inferirse que la rebe-

45 Los grupos parlamentarios del PNV y Coalición Canaria se opusieron incluso a que la voluntad de declarar la independencia de una parte del territorio nacional pudiera constituir una de los fines del delito de rebelión. Sobre ello, vid. Manzanares Samaniego, J. L.: "El Código Penal en el proceso independentista de Cataluña", en Diario La Ley, nº 9061, 2017, pp. 1 y ss.

46 En opinión de Morillas Cueva, L.: Sistema de Derecho penal. Parte especial, Madrid, 2016, p. 1248, el delito de rebelión es excesivamente casuístico, al presentarse como un ejercicio no especialmente logrado de regulación exhaustiva, farragosa y con deficiente redacción. Según él, la estructura de este delito está pensada más para afrontar posibles conductas futuras de rebelión que para responder al esquema de las sublevaciones militares que se han ido sucediendo en España hasta no hace mucho.

47 A favor de incluir la amenaza de usar la fuerza física en el concepto de violencia, Sandoval, J. C.: El delito de rebelión. Bien jurídico y conducta típica, Valencia, 2013, pp. 326 y ss., explica que en caso contrario un alzamiento pacífico, pero amenazador, para conseguir alguno de los fines previstos en el art. $472 \mathrm{CP}$ quedaría impune por atípico.

48 ATSJPV 25/2007, de 27 de noviembre; ATSJC 37/2014, de 24 de marzo. 
lión tiene suficiente entidad como para disuadir a las fuerzas del orden de actuar, al tener éstas indicios racionales para presumir que cualquier oposición a los planes subversivos convertirá el alzamiento en más belicoso, con el consiguiente riesgo de "derramamiento de sangre".

La exigencia explícita de violencia como medio comisivo puede reputarse superflua de considerarse que la idea de un alzamiento público supone, por definición, algo más que una mera declaración pública ${ }^{49}$. Ahora bien, al margen de lo anterior, la referencia genérica a la noción de violencia en el tenor literal del tipo, sin concretar éste las clases de la misma específicamente incriminadas, podría contravenir el principio de legalidad al ser contraria al mandato de determinación, según el que el ciudadano debe poder conocer en el momento de actuar los rasgos esenciales de la conducta prohibida u ordenada por la norma primaria (exigencia de ley previa). Esta ambigüedad en la definición del tipo ha propiciado la aparición de dos visiones contrapuestas respecto las formas de violencia sancionadas por el delito de rebelión, ambas apoyadas en razonamientos de corte sistemático.

Para una corriente doctrinal, en esta figura la violencia se referiría únicamente al empleo de fuerza física sobre las personas, habida cuenta de que en otros tipos contra la Constitución el legislador se refiere expresamente a la "intimidación" cuando quiere incorporarla como medio comisivo, como ocurre con los delitos contra la Corona o contra las instituciones del Estado previstos, respectivamente, en los arts. 489 y 503 CP. En cambio, para otro sector, se criminalizaría también la violencia psicológica o intimidación, toda vez que el uso efectivo de la violencia física está expresamente castigado como una modali-

49 Inicialmente, tanto el grupo parlamentario socialista como el de IU-IC se mostraron contrarios a exigir expresamente que la conducta típica tuviera carácter violento, por considerar que éste es inherente a la idea de alzamiento. Vid. Manzanares Samaniego, J. L.: "El Código Penal en el proceso independentista de Cataluña", en Diario La Ley, n 9061, 2017, pp. 1 y ss. 
dad agravada de rebelión en los arts. 473.2 y 479 CP (relativos, respectivamente, a la producción de combate entre los sectores leales a la autoridad legítima y los rebeldes o a que éstos rompan fuego).

Ciertamente, las interpretaciones del alcance del concepto de violencia en el delito de rebelión de carácter sistemático conducen a resultados contradictorios entre sí. Ahora bien, de completarse éstas con determinadas observaciones de índole teleológico-funcionalista, la balanza se decanta claramente a favor de la segunda postura, toda vez que, cuanto más peligroso es el alzamiento para el bien jurídico, en principio menos necesario resulta el efectivo uso de fuerza física para la consecución de los fines perseguidos por los rebeldes. Por lo tanto, si las dimensiones de un alzamiento con violencia psicológica pueden ser superiores a las de otro con violencia física, resultan incontestables las razones político-criminales para defender la integración de la amenaza del recurso a la fuerza física entre las modalidades típicas del delito de rebelión ${ }^{50}$.

50 Por lo demás, obviamente en el delito de rebelión no cabe apreciar causas de justificación. La perpetración de este delito suele ir acompañada de la apelación a razones excepcionales de necesidad, que no pueden conducir a la apreciación de la eximente de estado de necesidad del art. 20.5 CP al no contener la CE cláusulas de intangibilidad, toda vez que la integridad de sus preceptos puede ser reformada con arreglo a los procedimientos legales en ella establecidos. Es decir, al prever la CE mecanismos de reforma de sí misma, nada justifica jurídicamente el recurso a vías de hecho para modificarla o derogarla. En el juicio por el golpe de Estado del 23-F, los conjurados alegaron temer un mal efectivo, real, actual e inminente para la nación española, representado por el independentismo y el comunismo, para cuya evitación estimaron necesario abolir el sistema democrático y la CE, con la consiguiente sustitución del gobierno legítimo por otro encabezado por los insurgentes. Sin embargo, el TS decretó en su sentencia la inexistencia de un peligro individual, específico y determinado que amenazara con destruir bienes jurídicos titularidad de los acusados. Y, en cuanto a los peligros colectivos o supraindividuales eventualmente procedentes del terrorismo y el separatismo, la Sala estimó que tampoco existía estado de necesidad, habida cuenta de que los sublevados ni siquiera habrían agotado los medios pacíficos para evitarlos. 
No obstante, la intimidación a los poderes legalmente constituidos, a través de la amenaza de usar la fuerza física para conseguir los fines previstos, debe expresarse con actos concluyentes. Ahora bien, ello no implica que la violencia en el delito de rebelión pueda revestir cualquiera de las formas previstas en la legislación penal, al excluirse la violencia moral, esto es, actos que atenten contra la dignidad o integridad del sujeto pasivo en los términos del delito del art. $173 \mathrm{CP}$, al no ser éste un medio idóneo o suficientemente adecuado para la lesión del bien jurídico. Por las mismas razones, se excluye también del círculo de posibles medios comisivos la fuerza sobre las cosas, entendida como aquella aplicada sobre éstas para destruirlas o inutilizarlas. Así pues, la fuerza en las cosas sólo puede ser relevante desde la óptica del delito de rebelión cuando sea el medio para perpetrar la intimidación o para ejercer violencia física sobre el cuerpo de los destinatarios de ésta.

En atención a que el tenor literal del tipo se refiere genéricamente al empleo de "violencia", la inclusión de la violencia psicológica entre los medios comisivos del delito no supone recurrir a una aplicación analógica de la ley, sino a una interpretación de la figura compatible con su tenor literal. Así pues, a la luz de las finalidades de protección del tipo, resulta político-criminalmente coherente incriminar sublevaciones planeadas y ejecutadas de forma incruenta pero intimidatoria ( $\sin$ "vis física" pero con "vis psíquica"), así como alzamientos que fracasan por el motivo que sea en los que no llegan a realizarse actos de violencia física contra las personas jurídico-penalmente significativos.

En cuanto a las finalidades enunciadas en la descripción típica, éstas conforman un elemento subjetivo del injusto al trascender el dolo de la conducta relativo a la realización de un alzamiento público y violento. El elemento común a estos fines es la voluntad de atentar contra aspectos nucleares del orden constitucional de los que depende la vigencia de éste. Así pues, los insurgentes deben albergar la intención de ocasionar una alteración grave en el normal funcionamiento de determinadas 
instituciones estatales, hasta el punto de provocar la derogación, suspensión o modificación de la Constitución al margen de los procedimientos para reformarla que ella misma prevé ${ }^{1}$.

Desde la óptica del principio de proporcionalidad, la severidad de los marcos penales previstos refuerza la necesidad de reservar el delito de rebelión para los alzamientos públicos de mayor entidad. Así pues, aunque no se trate de un delito especial propio tan sólo susceptible de ser cometido por miembros de las Fuerzas Armadas, lo cierto es que el alzamiento público y violento de naturaleza civil únicamente puede integrar el delito de rebelión cuando disponga de la misma potencialidad lesiva para el bien jurídico que una sublevación de origen militar. Según ello, dado que una insurrección militar puede punirse con arreglo al delito de rebelión, aunque no sea previsible que degenere en una guerra civil, este atributo tampoco puede ser una exigencia para el castigo del alzamiento civil. Ahora bien, por imperativo de los principios de lesividad y proporcionalidad, el alzamiento civil cuanto menos debe ser adecuado, por un lado, para provocar un enfrentamiento físico entre los rebeldes y los sectores leales al poder legítimo y, por otro, para forzar una declaración de estado de sitio de acuerdo con el art. $116 \mathrm{CE}$, al ser éste el mecanismo más expeditivo del que dispone el Estado para repeler una amenaza contra el orden constitucional.

Esta concepción de la mínima lesividad de la conducta típica casa con el tratamiento militar tradicionalmente recibido por esta figura. De hecho, dentro de la gradación de los marcos penales del tipo básico, el art. 473.1 CP condiciona la determinación de la pena a las funciones y al rango de los autores y partícipes, lo que remite a la lógica de una estructura de poder organizada jerárquicamente como es la militar. La pena establecida para los diversos responsables se modula según su posición en la escala de mando, por lo que la inducción incluso puede

51 Sobre la naturaleza de "numerus clausus" de los fines previstos en el delito de rebelión, Magro Servet, V.: "Casuística práctica y jurisprudencial de los delitos de rebelión y sedición”, en Diario La Ley, n 9074, 2017, pp. 1 y ss. 
ser más relevante que la ejecución material. En esta línea, dentro de los autores se diferencia entre jefes principales y jefes no principales, asimilándose estos últimos a sujetos que ejercen un mando de naturaleza subalterna. En consecuencia, el art. 473.1 $\mathrm{CP}$ introduce un régimen especial de atribución de responsabilidad penal, a aplicar con preferencia a lo dispuesto con carácter general en los arts. 27,28 y $29 \mathrm{CP}$, del que se desprende que en el delito de rebelión no cabe la participación. A los inductores que promuevan o sostengan la rebelión y a los jefes principales de la misma se les impondrá una pena de prisión de quince a veinticinco años y de inhabilitación absoluta por el mismo tiempo; mientras que los que ejerzan un mando subalterno, serán sancionados con prisión de diez a quince años e inhabilitación absoluta de diez a quince años. Por su parte, los meros participantes serán castigados con pena de prisión de cinco a diez años e inhabilitación especial para empleo o cargo público por tiempo de seis a diez años.

Hasta aquí se ha expuesto que las diferencias entre el delito de rebelión y el de sedición no radican en la naturaleza de los medios empleados, al tener que ser el alzamiento público y violento en ambos casos, sino en el distinto interés tutelado en cada uno de ellos ${ }^{52}$. Mientras que en la rebelión se socavan los fundamentos del Estado de Derecho, en la sedición tan sólo se perturba el normal funcionamiento del mismo a través del intento de impedir la aplicación de las leyes o el legítimo ejercicio de la autoridad. La menor entidad de los fines ilícitos perseguidos en la sedición determina la inclusión de ésta entre los delitos que salvaguardan el ordinario y pacífico desarrollo de las diversas

52 De forma similar al delito de sedición en España, el art. 113 del CP alemán, encuadrado dentro de los delitos contra la autoridad o poder del Estado, castiga, de forma claramente diferenciada respecto los delitos contra la existencia del Estado, los atentados contra el poder de ejecución de éste, esto es, contra la puesta en marcha o realización de su voluntad. Sobre como con este delito se pretende tutelar la actividad o función ejecutiva del Estado, Javato Martín, A.: “¿Existe el delito de sedición en Alemania, Suiza y Bélgica?", en Diario La Ley, no 9188, 2018, pp. 1 y ss. 
manifestaciones externas de la vida ciudadana (orden público). Esto explicaría la decimonónica calificación de la sedición como una "rebelión en pequeño" o "rebelión de segundo grado" 53 .

No obstante, una parte de la doctrina sostiene que para la sedición basta con actuar "fuera de las vías legales", esto es, al margen de los procedimientos de reclamación o disconformidad arbitrados o prescritos por la ley, sin que sea imprescindible el empleo de violencia física o psicológica como medios para la insurrección ${ }^{54}$. A mi modo de ver, esta postura según la que la violencia no siempre caracteriza el alzamiento sedicioso resulta criticable por un doble motivo: el primero, de orden gramatical, toda vez que semánticamente sería inherente al concepto de alzamiento el carácter violento del mismo; y el segundo, de índole teleológica, por cuanto las insurgencias públicas y tumultuarias desplegadas sin violencia podrían alojarse de manera más satisfactoria en otras figuras por razones vinculadas a los principios de lesividad y proporcionalidad, como la de desórdenes públicos del art. $557 \mathrm{CP}$, de desobediencia del art. $556 \mathrm{CP}$ o de prevaricación del art. $404 \mathrm{CP}$.

Así pues, desde este punto de vista tanto el alzamiento rebelde como el sedicioso requerirían algo más que una actuación ilícita, ilegítima o ilegal. Tanto en la rebelión como en la sedición se actuaría colectivamente en abierta hostilidad exteriorizada a

53 Magro Servet, V.: "Casuística práctica y jurisprudencial de los delitos de rebelión y sedición”, en Diario La Ley, no 9074, 2017, pp. 1 y ss. A criterio del autor, a través de la protección del orden público también se intenta garantizar la aplicación de las leyes, de los acuerdos y resoluciones administrativas o judiciales.

Precisa Peris Riera, J. M.: Sistema de Derecho penal. Parte especial, Madrid, 2016, p. 1337, que el orden público nunca puede ser interpretado en el sentido de una cláusula preventiva frente a eventuales riesgos puesto que la misma sería un peligro para el ejercicio del derecho a la libertad.

54 STS de 10 de octubre de 1980. A favor de que la incriminación de conductas no violentas ni intimidatorias realizadas fuera de las vías legales permite incluir en el tipo de sedición manifestaciones de corte político sin cobertura legislativa, Peris Riera, J. M.: Sistema de Derecho penal. Parte especial, Madrid, 2016, p. 1338 y ss. 
través del uso de la fuerza física o de la amenaza de recurrir a la misma. Consiguientemente, si una sedición pacífica (o "fuera de las vías legales") no puede equipararse axiológicamente a una sedición violenta (con fuerza física o psicológica), no cualquier entorpecimiento público y colectivo del normal desempeño de las funciones estatales integra el delito previsto en el art. $544 \mathrm{CP}$. Esta interpretación resulta político-criminalmente satisfactoria a la vista de que en la práctica difícilmente podrán conseguirse los "fines" sediciosos sin recurrir a medios violentos.

Por otro lado, la sedición también se configura como un delito plurisubjetivo de convergencia y de resultado cortado, de manera que la consumación no depende del logro de las finalidades subjetivas descritas en el tipo. Asimismo, el delito de sedición también se estructura como un tipo penal de mera actividad y de peligro abstracto. Y, en otro orden de cosas, tanto en la rebelión como en la sedición existe una finalidad común de subversión política o social, lo que no significa que la diferencia entre ambas figuras sea meramente cuantitativa al ser diferentes los fines perseguidos en cada caso ${ }^{55}$. Así pues, ambas figuras se caracterizarían por la existencia de una dinámica colectiva de carácter violento, destinada en un caso a la subversión del orden constitucional y en el otro a atacar el normal desarrollo de las actividades y servicios públicos.

En contra de la opinión de un sector de la doctrina, la exigencia de que el alzamiento sedicioso tenga lugar "tumultuariamente" no tiene por qué conectarse con la producción de un alboroto por parte de una muchedumbre ni, por lo tanto, supone que la sublevación tenga que ser anárquica, inorgánica, desordenada o en tropel. Así pues, la exigencia de que el alzamiento sea tumultuario no impediría que el mismo pueda estar cuidadosamente organizado y ordenado ${ }^{56}$. Según ello, la carga semántica del adverbio "tumultuariamente" se limitaría al carácter público

55 STS de 3 de julio de 1991.

56 En el mismo sentido, STS de 10 de octubre de 1980. 
del alzamiento, en cuyo caso se configuraría como una previsión reiterativa. Desde esta perspectiva, tanto en la rebelión como en la sedición lo determinante es la existencia de un levantamiento colectivo y violento, más o menos organizado, en el que tan sólo varía el nivel de conmoción social a producir en cada caso.

En ambas manifestaciones delictivas bastaría con un alzamiento de una pluralidad de personas de forma abierta (cognoscible para terceros), en el que se recurra a la fuerza física o a la amenaza de uso de la misma, con independencia de si la actuación de los agentes está más o menos planificada o coordinada, de modo que ésta puede ser totalmente espontánea. Basta entonces con la existencia de un acuerdo mutuo entre los alzados, que puede surgir incluso durante la ejecución, en los mismos términos que en la coautoría en general. Por su parte, en la fase de actos preparatorios, si los autores conspiran para cometer el delito, para la punibilidad de su actuación es suficiente con el concierto para ejecutar el alzamiento y la resolución de hacerlo.

Si la rebelión y la sedición se diferencian entre sí porque en la primera se actúa con el fin de abolir o dinamitar el Estado de Derecho, mientras que en la segunda tan sólo se trata de obstruir la correcta y normal prestación de sus servicios, no podría plantearse entre ambas figuras ningún concurso de leyes. Ahora bien, de contemplarse la rebelión como una simple intensificación cualitativa respecto el ataque al sistema jurídico que representa la sedición, las zonas de contacto entre la conducta típica y el bien jurídico permitirían conformar un concurso de leyes a resolver a favor del precepto regulador del delito de rebelión con arreglo al principio de especialidad (art. 8.1 CP). Asimismo, este eventual concurso de leyes entre ambas disposiciones también podría resolverse considerando que entre ellas existe una relación de subsidiariedad expresa (art. 8.2 CP), en cuyo caso la principal sería la reguladora de la rebelión y la subsidiaria la que contempla la sedición. Por lo demás, al margen de si los delitos de rebelión y sedición se dirigen o no a la salvaguarda del mismo bien jurídico y, por lo tanto, de si el primero se configura o no como una simple agravación del segundo, parece que toda 
conducta constitutiva de un delito de rebelión debe ser, además, subsumible en un delito de sedición, toda vez que la objetiva idoneidad del comportamiento rebelde para derogar la actual forma de Estado implicaría necesariamente la adecuación del mismo para alterar el normal funcionamiento de éste.

Tanto en el delito de rebelión como el de sedición la conducta de los sujetos activos debe estar dotada de determinadas connotaciones reivindicativas en el terreno político o social, en la medida que ambas figuras protegen algo más que el pacífico desarrollo de las distintas manifestaciones de la vida ciudadana ${ }^{57}$. Según ello, son de aplicación preferente otras tipologías delictivas cuando el alzamiento, pese a surgir como consecuencia del descontento producido por determinadas situaciones político-sociales, tan sólo comprometa el legítimo ejercicio de la autoridad o el desempeño de las funciones públicas, sin actuar los sujetos activos por razones ideológicas.

Dado que existen tipos penales menos graves que el delito de sedición para castigar conductas realizadoras del tenor literal de éste (delitos de desórdenes públicos, de desobediencia, prevaricación, etc.), cuando una insurrección pública realizada con violencia física o intimidación no sea en el momento de emprenderse objetivamente adecuada para obstaculizar el ejercicio de la autoridad, o para obstaculizarlo de un modo relevante desde la óptica del delito de sedición, el comportamiento debe considerarse atípico en virtud de la ausencia de riesgo para el específico objeto de tutela de esta infracción o del principio de insignificancia (con reconducción, en su caso, de la actuación a otras tipologías delictivas). Según ello, en el delito de sedición la consumación depende del acometimiento de una sublevación ex ante objetivamente adecuada para alterar de forma grave el normal desarrollo de las funciones estatales ${ }^{58}$.

57 En esta línea, la jurisprudencia ha desvinculado el alzamiento público y tumultuario del delito de sedición cuando no existe un móvil político o social (STS de 3 de julio de 1991).

58 De verificarse ex post que la sedición no ha producido efectivamente este resultado y que, por lo tanto, no ha alcanzado el objetivo que la impulsaba, 
Desde un punto de vista objetivo, tanto el alzamiento rebelde como el sedicioso suponen una alteración inmediata del orden público, pero en ambos casos lo que se castiga no es esa alteración en cuanto tal, sino la adecuación de la misma para la realización de alguna de alguna de las finalidades típicas. Así pues, no es suficiente con que los rebeldes o sediciosos actúen con alguna de las intenciones típicas, sino que además la consecución del objetivo propuesto debe ser una consecuencia previsible de su actuación.

Así las cosas, en sí mismo un alzamiento no resulta penalmente antijurídico, sino que sólo puede adquirir relevancia para el Derecho penal si busca unos determinados objetivos y se realiza empleando unas determinadas dinámicas comisivas. Cuando un alzamiento público y violento no sea adecuado para lesionar el orden constitucional democrático, sólo subsidiariamente podrá ser calificado como sedicioso, en cuyo caso el comportamiento deberá encaminarse a obstaculizar la aplicación de las leyes o a entorpecer el legítimo ejercicio de sus funciones a las autoridades o funcionarios públicos.

\section{Actos preparatorios punibles}

Aunque conceptualmente puedan ser espontáneas, a nivel fáctico resulta difícil imaginar una rebelión o sedición sin actos preparatorios, puesto que la propia dinámica comisiva de las mismas en principio presupone una cierta preparación de la ejecución. El legislador, consciente de esta circunstancia, ha incriminado la provocación, la conspiración y la proposición tanto para cometer rebelión (art. $477 \mathrm{CP}$ ) como sedición (art. 548 $\mathrm{CP}$ ). Confirma el acierto de esta opción legislativa el carácter plurisubjetivo de convergencia de estas infracciones, al resultar

consistente en entorpecer de modo grave el ejercicio de la autoridad pública, el art. 547 CP prevé una rebaja obligatoria de la pena en uno o dos grados, siempre que el hecho no sea constitutivo de otro delito al que la ley señale penas graves. 
especialmente insidiosa o peligrosa la implicación de terceras personas en un proyecto criminal cuyo éxito depende indefectiblemente del concurso de las mismas.

En el delito de rebelión el tratamiento de los actos preparatorios punibles no difiere sustancialmente del que reciben en otros delitos, al imponerse la pena inferior en uno o dos grados. Desde esta perspectiva, la apología de la rebelión debe considerarse como una forma de provocación. En el art. $475 \mathrm{CP}$ se tipifica una modalidad específica de actos preparatorios punibles, cuyos autores son asimilados a los rebeldes desde una óptica penológica, consistente, como delito común, en seducir o allegar tropas o cualquier otra clase de fuerza armada para cometer el delito de rebelión. El párrafo segundo agrava la asimilación cuando llega a tener efecto la rebelión, en cuyo caso los sujetos se consideran promotores de la misma y, por ende, acreedores de las penas señaladas en el art. $473 \mathrm{CP}$ para los inductores o jefes principales de la insurrección ${ }^{59}$.

En el delito de sedición, los actos preparatorios punibles también se castigan con la pena inferior en uno o dos grados, salvo que se lleve a efecto el alzamiento, en cuyo caso a los conjurados se les impone la misma pena que a los promotores establecida en el art. $545 \mathrm{CP}$. Es decir, en este supuesto los preparadores reciben el mismo tratamiento penológico que los inductores, sostenedores, directores y principales autores de la sedición.

En todo caso, tanto en el delito de rebelión como en el de sedición la provocación, la conspiración o la proposición para delinquir deben serlo respecto la ejecución del tipo cuya ejecución se proyecta ${ }^{60}$. Así pues, en ambos supuestos los sujetos

59 Vid. Morillas Cueva, L.: Sistema de Derecho penal. Parte especial, Madrid, 2016, p. 1252.

60 En cuanto a los acontecimientos vinculados al llamado proceso independentista catalán, se decretó que la aprobación de mociones municipales de apoyo y adhesión a la resolución 1/XI del Parlament de Catalunya, de 3 de noviembre de 2015, invalidada por el TC, no constituye delito de rebelión 
deben actuar con el ánimo de preparar un alzamiento público y violento. Es decir, con la voluntad de que se realice una futura actuación insurreccional que comprenda actos colectivos de violencia física o psicológica. $\mathrm{O}$, cuanto menos, debe existir dolo eventual respecto de estas circunstancias, en el sentido de que los autores de los actos preparatorios no estimen posible descartar que la futura sublevación se traduzca en actos de violencia física o psicológica si éstos son necesarios para la consecución de los ilegales fines que se proponen.

Sentado lo anterior, queda por establecer el momento en el que acaban los actos preparatorios y comienza la ejecución del delito de rebelión ${ }^{61}$. Esta es una cuestión de suma trascendencia al marcar el límite entre los actos punibles (actos ejecutivos) y los impunes o, en su caso, castigados con una pena inferior en uno o dos grados respecto los ejecutivos (actos preparatorios). $\mathrm{Si}$ bien la determinación de la línea divisoria entre las fases de preparación y ejecución del delito es siempre una tarea sumamente ardua por tratarse de una materia en la que confluyen múltiples criterios antagónicos entre sí, sin gozar ninguno de ellos de una aceptación doctrinal mínimamente generalizada, aquí va a defenderse que sólo empiezan a ejecutar el tipo cuya perpetración se ha proyectado las conductas que formalmente inician su realización, lo que tan sólo sucede con aquellas subsumibles en el verbo rector del tipo en sentido literal (criterio formal) ${ }^{62}$. A su

o sedición, al no incluir una proposición a los ciudadanos para que se alcen pública y violentamente. Ni tampoco de manera tumultuaria o desordenada, $\mathrm{u}$ hostil o amedrentadora. Se alega que un llamamiento de esta naturaleza sería contrario a la expresión "pacífica" utilizada en dichas mociones (AAN de 8 de febrero de 2016).

61 La propia definición legal de tentativa del art. $16 \mathrm{CP}$, como "dar principio a la ejecución del delito", obliga a distinguir entre actos preparatorios y ejecutivos pero, sin embargo, no ofrece ningún criterio para ello, como destaca Moreno-Torres Herrera, M. R.: Tentativa de delito y delito irreal, Valencia, 1999, pp. 227 y ss.

62 En relación con ello me adscribo al planteamiento de MiR PUIG, S.: "Sobre la punibilidad de la tentativa inidónea en el nuevo Código Penal", en Revista de Derecho Penal y Criminología, $\mathrm{n}^{\circ} 3,2001$, pp. 1 y ss. 
vez, la decisión acerca de si es o no posible realizar esa subsunción depende de un criterio objetivo-subjetivo, es decir, de una valoración objetiva del plan del autor ${ }^{63}$. Cuando la conducta literalmente típica está compuesta por una pluralidad de movimientos físicos o corporales, éstos se integran valorativamente en la unidad de significado que expresa el verbo rector del tipo, sin que en ningún caso sea necesario esperar a la realización del último de ellos (criterio material). Para saber si un determinado movimiento corporal queda o no incluido en esa unidad de significado hay que recurrir necesariamente a parámetros sustantivos como los usos ordinarios del lenguaje, el riesgo generado por la conducta o la proximidad temporal entre ésta y la lesión del bien jurídico ${ }^{64}$.

Así pues, la adopción de una posición mixta de carácter objetivo-subjetivo parece ser la más razonable para resolver el problema del inicio de la ejecución. Desde esta perspectiva, el significado que el autor confiere a su conducta es un elemento determinante para valorar si la misma es preparatoria o ejecuti$\mathrm{va}^{65}$. Consecuentemente, en una solución de síntesis en la que se combinen criterios objetivos y subjetivos, la forma en la que el

63 En el mismo sentido, Reyes Alvarado, Y.: El delito de tentativa, Montevideo / Buenos Aires, 2016, p. 276.

64 Se parte en esta visión de la descripción legal de la conducta típica, según la imagen que el autor tiene sobre el curso de los acontecimientos. En función de esta imagen se pondera si el comportamiento realizado está tan estrechamente ligado a la conducta típica que prácticamente no quedan eslabones intermedios esenciales para poner en actividad la inmediata realización del tipo. Al respecto, Muñoz Conde, F. / García Arán, M.: Derecho Penal. Parte General, Valencia, 2010, pp. 417 y ss.

65 De fundamentarse la punibilidad del hecho en la representación del autor sobre el mismo, se ampliaría excesivamente el campo de los actos considerados ejecutivos, lo que resultaría poco respetuoso con las garantías del ciudadano, toda vez que el juez debería determinar de forma arbitraria y discriminatoria si el sujeto ha exteriorizado realmente una voluntad criminal, según sus antecedentes personales: psicológicos, historia de vida, comportamiento en general, etc. Sobre ello, Bustos Ramírez, J.: Manual de Derecho Penal. Parte General, Barcelona, 1989, pp. 272 y ss. 
autor tiene proyectada la ejecución del delito se tomaría en consideración, pero valorándola con arreglo a módulos objetivos, esto es, de acuerdo con la opinión de un espectador imparcial. Más concretamente, desde esta óptica la conducta sería ejecutiva cuando inicie la realización del tipo según la opinión de un espectador objetivo que conoce el plan del autor. Para esta valoración objetiva del plan criminal del autor pueden ser útiles criterios materiales como, en primer lugar, el de la inmediatez o conexión temporal de los actos, en virtud del que la ejecución se inicia cuando la conducta se desarrolla en un momento temporalmente muy próximo a la consumación, esto es, cuando no existen eslabones intermedios entre el comportamiento de que se trate y el perfeccionamiento delictivo; o, en segundo lugar, el de la puesta en peligro del bien jurídico, según el que la ejecución comienza cuando existe un riesgo objetivo para el bien jurídico según la representación del autor sobre su hecho ${ }^{66}$. Ahora bien, por imperativo directo del principio de legalidad, en ningún caso el campo de la ejecución podría ampliarse a actos anteriores al comportamiento típico en sentido estricto o literal (criterio formal) ${ }^{67}$.

Desde este punto de vista, una conducta puede ser ejecutiva o preparatoria en función del plan del autor. En consecuencia, en relación con el delito de rebelión habrá que valorar

66 De esta forma el principio de la ejecución se vincula a la idoneidad de la conducta para la consecución del fin propuesto. Sobre ello, sostiene Moreno-Torres Herrera, M. R.: Tentativa de delito y delito irreal, Valencia, 1999, pp. 236 y ss., que "sí podemos concluir afirmando, con carácter general, que para poder hablar de que existe un principio de ejecución que nos permita afirmar que estamos ante una tentativa de delito es necesario que los actos que la integran sean idóneos, entendida dicha idoneidad como adecuación ex ante de la acción en relación con el resultado perseguido".

67 A juicio de algunos autores, en los delitos de mera actividad tan sólo es admisible la tentativa si se entiende que la misma puede empezar con un acto previo a la ejecución en sentido estricto, como apunta Quintero Olivares, G.: Parte General del Derecho Penal, Pamplona, 2007, pp. 592 y ss. Personalmente considero que esta postura supondría una flagrante vulneración del principio de legalidad. 
el modo en que los autores habían planificado la realización del tipo. Habrá ejecución cuando el espectador objetivo pueda llegar a la conclusión de que el plan criminal de los autores ha entrado en la fase decisiva de ejecución, con independencia de la opinión de éstos sobre su hecho. Cuanto mayor sea el peligro para el orden constitucional y la conducta más cercana esté temporalmente de la efectiva lesión del mismo, mayores serán las razones para considerar que los actos en cuestión realizan el verbo rector del tipo, esto es, que forman parte del alzamiento público y violento que éste describe. Por lo tanto, conforman el alzamiento público y violento del delito de rebelión los actos que suponen una puesta en peligro inmediata del bien jurídico temporalmente muy próximos a su lesión.

Naturalmente, la conducta consistente en alzarse de forma pública y violenta está compuesta por múltiples movimientos corporales específicos procedentes de diferentes sujetos, pero en todo caso por razones de seguridad jurídica las conductas anteriores a la realización del tipo en sentido formal -esto es, anteriores al alzamiento- deben considerarse preparatorias de la ejecución, en cuyo caso debe imponerse la pena inferior en uno o dos grados de ser punibles. Cuando no puede afirmarse que los sujetos "han empezado a alzarse" según la planificación criminal de los mismos valorada objetivamente, la impunidad o la imposición de una pena menor resulta a todas luces proporcional.

En suma, el inicio de la ejecución depende de la representación del autor sobre su hecho, porque la realización del delito puede adoptar múltiples modalidades comisivas a elección de él. La unidad de significado de los distintos movimientos físicos de los que se compone la conducta literalmente típica depende de su conexión temporal con la lesión del bien jurídico, así como del peligro que supongan para éste. Se adopta, por consiguiente, un criterio de delimitación mixto en el que el plan del autor (aspecto subjetivo) se examina desde un punto de vista de un espectador imparcial (aspecto objetivo), en virtud del cual sólo son objetivamente ejecutivos los actos subsumibles en el tenor literal del verbo típico (aspecto formal), valorado éste 
como una unidad de sentido compuesta por varios movimientos físicos temporalmente conectados entre sí y que ponen en peligro el interés atacado (aspecto material). De este modo se refuerza la previsibilidad del sistema, por cuanto se proporciona a los ciudadanos un conocimiento certero de los comportamientos prohibidos u ordenados, lo que permite optimizar la eficacia motivadora de la norma primaria.

En atención a que en los actos preparatorios puede identificarse un peligro para el bien jurídico que va aumentando cuantitativamente hasta la efectiva lesión del mismo, lo determinante es decidir a partir de qué "grado" el peligro reviste suficiente entidad como para dar comienzo a la ejecución ${ }^{68}$. Para ello resultan útiles el criterio objetivo-subjetivo propuesto en el que se combinan consideraciones de índole formal y material a valorar conjuntamente como pautas orientativas. En el caso del delito de rebelión, al tratarse de un tipo de peligro abstracto, conforman el alzamiento típico aquellos actos públicos de carácter violento suficientemente lesivos como para amenazar la continuidad del orden constitucional de una forma que tan sólo pueda ser neutralizada a través de la intervención militar inherente a una declaración de estado de sitio.

\section{El recurso a la abstracción en la técnica legislativa empleada}

La tendencia a la normativización propia de las descripciones típicas de la Parte especial resulta lógica al aspirar éstas a dar una respuesta general ante unos determinados elementos fácticos, lo que impone el deber de formular sus enunciados con un cierto grado de abstracción. Ahora bien, si no se quiere

68 En opinión de Rey SAnfiz, L. C.: La tentativa jurídico-penal. Acercamiento al tratamiento doctrinal del fundamento de los criterios de imputación entre naturalismo y normativismo, Madrid, 2001, pp. 37 y ss., desde el primer acto de preparación hasta la consumación, tan sólo puede establecerse una continuada intensificación cuantitativa de la peligrosidad de la actuación del sujeto. 
conculcar el principio de seguridad jurídica $(9.3 \mathrm{CP})$ ni el derecho a la legalidad penal (art. 25.1 CE), esta propensión a la abstracción debe ser compatible con la existencia de un número razonable de posibilidades de conocimiento del núcleo esencial de la prohibición. Una excesiva volatilización del contenido de la norma primaria puede derivar en un quebrantamiento de las mínimas exigencias de certeza, con la consiguiente creación de un amplísimo margen de inseguridad jurídica ni siquiera susceptible de ser paliado por vía interpretativa. Expresado en otros términos, la inevitable tendencia a la normativización de las formulaciones típicas no puede degenerar en una insuficiente precisión en la ley de las conductas calificadas de delictivas ni, por ende, en una obstrucción de la función de límite de garantía que cumple el tipo penal en orden a dar a conocer las actuaciones conminadas con una pena.

Para cumplir con las exigencias derivadas del principio de legalidad, la técnica legislativa empelada debe respetar las manifestaciones del mismo relativas a las garantías, por un lado, de taxatividad o lex certa, según la que la ley debe definir la conducta prohibida u ordenada con la mayor precisión posible; $\mathrm{y}$, por otro, de tipicidad o lex stricta, en virtud de la que la aplicación de la ley debe someterse al sentido gramatical y axiológico del precepto, de modo que resulte previsible para sus destinatarios. Según ello, los mandatos derivados de las exigencias de taxatividad y tipicidad se dirigirían, respectivamente, al legislador y a los tribunales. En cuanto a la garantía de taxatividad, el $\mathrm{TC}$ ha venido asumiendo expresamente un cierto "principio de deferencia" hacia el legislador democrático ${ }^{69}$, según el que se

69 Como señala Martínez Estay, J. I.: "Auto-restricción, deferencia y margen de apreciación. Breve análisis de sus orígenes y de su desarrollo", en Estudios Constitucionales, Vol. 12, n ${ }^{\circ} 1,2014$, pp. 1 y ss., las relaciones entre el legislador y los jueces constitucionales han de estar presididas por un principio de deferencia hacia el primero que supone una auto-restricción para los segundos. Según ello, se reconoce una cierta autonomía al legislador para gozar, dentro de los márgenes fijados por la Constitución, de libertad para el ejercicio de su función. Esta libertad o autonomía comprende, básicamente, 
presupone la constitucionalidad de las normas con rango de ley emanadas del Parlamento. Desde este punto de vista, corresponde en exclusiva al legislador el diseño de la Política criminal, para lo que éste goza, dentro de los límites establecidos en la Constitución, de un amplio margen de libertad procedente justamente de su legitimidad democrática. Apelando a este principio de conservación de ley, el TC sólo puede decretar la inconstitucionalidad de un precepto cuando, tras explorar todas las posibilidades interpretativas del mismo, ninguna permita salvaguardar la primacía de la Constitución ${ }^{70}$.

En atención a que un enfoque teleológico-funcionalista lleva a la admisión de un cierto grado de apertura de la norma a la interpretación, en cuyo caso el principio de taxatividad no operaría con un rigor extremo, el núcleo del problema reside en la determinación de qué grado de imprecisión resulta intolerable en la definición del delito de rebelión ${ }^{71}$. El grado de certeza jurídica es suficiente cuando existe la posibilidad de predecir el contenido de los actos del poder público a partir de la lectura

el conjunto de apreciaciones de mérito y oportunidad que llevan al legislador a la adopción de una u otra fórmula normativa. A su vez, las relaciones entre el Ejecutivo y los jueces constitucionales implican una presunción de legalidad y, en último término, de juridicidad de los actos del primero. Sobre como el control de constitucionalidad comporta que jueces sin legitimidad democrática directa controlen normas creadas por representantes electos de los ciudadanos, lo que produce una importante tensión entre la racionalidad jurídica y los principios puramente democráticos, por lo que la jurisdicción constitucional debe actuar con especial deferencia hacia el legislador, LÓPEZ Rubio, D.: "El control de constitucionalidad de la 'legislación popular", en Oñati Socio-legal Series, V. 7, n 5, 2017, pp. 931 y ss. Sobre como en relación con el legislador penal el TC se ha mostrado especialmente prudente y deferente, Lascuraín Sánchez, J. A.: "¿Restrictivo o deferente? El control de la ley penal por parte del Tribunal Constitucional", en Indret, $\mathrm{n}^{\circ}$ 3, 2012, pp. 22 y ss.

70 Vid. Alcácer Guirao, R.: "Taxatividad, reserva de ley y cláusulas de lesividad en las normas penales en blanco. Consideraciones al hilo de la STC 101/2012, de 8 de mayo", en Diario la Ley, $\mathrm{n}^{\circ} 7922$, pp. 3 y ss.

71 Vid. Ferreres Comella, V.: El principio de taxatividad en materia penal y el valor normativo de la jurisprudencia (una perspectiva constitucional), Madrid, 2002, p. 37. 
de los textos jurídicos vigentes en los que se hallan las normas reguladoras del ejercicio del aparato coercitivo. Se trata, en definitiva, de asegurar que los ciudadanos, tras consultar los textos jurídicos relevantes (por sí mismos o a través de especialistas), puedan anticipar cuáles serán las consecuencias penales de sus posibles acciones u omisiones. En consecuencia, el principio de taxatividad trata de evitar la incertidumbre que provoca no saber si se puede o no ser castigado por algo.

Sentado lo anterior, la finalidad de la reforma del delito de rebelión de 1995 fue, no sólo cambiar el enfoque del bien jurídico, sino también eliminar los déficits de taxatividad en la descripción de las conductas típicas, sobre todo a la vista de la severidad de los marcos penales previstos. Ahora bien, en el mejor de los casos este objetivo se ha logrado sólo parcialmente, al persistir problemas de indeterminación en relación con algunos elementos típicos, singularmente en lo que se refiere a la definición del concepto de violencia como medio comisivo. Así pues, más allá de la necesidad de satisfacer determinadas exigencias políticas, lo recomendable habría sido plasmar en el tipo las referencias a la "vis física" y a la "vis psíquica".

En la actualidad quedan fuera de la órbita del tipo de rebelión movimientos de carácter político que pretendan cambiar o derogar la Constitución fuera de los cauces legales sin organizar una insurrección pública y violenta ${ }^{72}$. Según se ha expuesto, la exigencia expresa de violencia resulta hasta cierto punto innecesaria ya que la idea de "alzamiento público" sugiere algo más que una simple acción política como puede ser una declaración pública. Así pues, aun en el supuesto de que la violencia no se contemplara explícitamente como medio comisivo, los rebeldes

72 A propósito de la proclamación del Estado catalán efectuada por Companys en octubre de 1934, ya se debatió profusamente acerca de si podía hablarse de un delito de rebelión cuando se había realizado una "mera" declaración política. Vid. García Rivas, N.: “¿Rebelión en Cataluña? La Fiscalía de la Audiencia Nacional persigue 'sombras rebeldes"', en Eunomía, n' 10, 2016, p. 93. 
deberían expresar, aunque sea de forma no verbal, su voluntad hostil y beligerante a través de actos concluyentes ${ }^{73}$. La aplicación del precepto a personas que promuevan alguno de los objetivos políticos enumerados en el tipo de modo democrático y no violento integraría, no una interpretación expansiva del precepto compatible con su tenor literal, sino una analogía contra reo ${ }^{74}$.

Según lo expuesto, el delito de rebelión presenta una excesiva carga de normatividad al no especificar las concretas clases de violencia que incrimina, lo que dificulta el conocimiento de la materia de prohibición hasta niveles de incertidumbre incompatibles con el principio de taxatividad de la ley penal. Según ello, el legislador debería haber empleado términos menos abstractos para precisar los medios comisivos del delito. Los déficits de determinación del precepto obligan a delimitar el círculo de conductas prohibidas con arreglo a criterios hermenéuticos tales como el teleológico-funcionalista. Así pues, desde la óptica de las finalidades de protección del tipo, resulta claro que sólo

73 Comparto la opinión según la cual no es necesario que los autores de la rebelión ejecuten materialmente los actos violentos, toda vez que, al tratarse de supuestos de coautoría, rige el principio de imputación recíproca de las distintas contribuciones. En opinión de Magro Servet, V.: "Casuística práctica y jurisprudencial de los delitos de rebelión y sedición", en Diario La Ley, $\mathrm{n}^{\circ}$ 9074, 2017, pp. 1 y ss., el delito de rebelión requiere una pluralidad de personas mínimamente organizadas para conseguir el objetivo común, de modo que éstos orquestan sus actos como un todo en una operación conjunta tendente a conseguir alguno de los fines previstos en el art. $472 \mathrm{CP}$.

74 Como explica Mir Puig, S.: "El delito de coacciones en el Código penal", en Anuario de Derecho Penal y Ciencias Penales, $\mathrm{n}^{\circ} 30-2,1977$, pp. 274 y ss., la evolución del concepto de violencia en los distintos textos legales que lo utilizan está marcada por su progresiva ampliación, lo que refleja la continua aparición de nuevas formas, cada vez más refinadas, de negar la libertad ajena, producto del constante aumento de los medios técnicos de los que el hombre dispone y que le permiten conseguir con mayores probabilidades de éxito y menor esfuerzo los mismos resultados que antes requerían el empleo de fuerza material. En relación con el delito de coacciones, el autor se muestra favorable a no restringir el concepto de violencia a la fuerza corporal ejercida sobre una persona, lo que le lleva a postular que en ella lo esencial no es el empleo de fuerza física, sino la abierta negación de la capacidad de decisión personal o de la realización externa de ésta. 
puede lesionar el bien jurídico la violencia que recaiga, aunque sea indirectamente, sobre bienes jurídico-penales individuales de carácter personal. Por consiguiente, los actos de fuerza sobre las cosas, contemplados aisladamente como un ataque contra el patrimonio, no pueden catalogarse como una expresión de violencia. La destrucción, manipulación o alteración del uso normal de un bien tan sólo puede ser relevante cuando constituya el medio a través del que se ejerce algunas de las formas típicas de violencia ${ }^{75}$.

Por otro lado, dado que la rebelión implica un componente de coacción al poder constituido, tampoco la violencia moral, en virtud de la que se infringe a la víctima un trato degradante o vejatorio atentatorio contra su dignidad en los términos del delito de torturas del art. $173 \mathrm{CP}$, sería un instrumento idóneo del delito del art. 472 CP. Así las cosas, la violencia típica del delito de rebelión podría revestir dos manifestaciones distintas: una, como violencia física, en cuyo caso la conducta debería ser constitutiva de un delito de lesiones o maltrato de obra del art. $147 \mathrm{CP}$ (o, claro está, de un delito de homicidio o asesinato de, respectivamente, los arts. 138 y $139 \mathrm{CP}$ ); y otra, como violencia psicológica o intimidación, mediante la que se anunciaría un mal constitutivo de un delito de lesiones, aborto, homicidio o asesinato, exigiéndose una prestación como condición para no verificarlo, en el sentido del delito de amenazas condicionales del art. 169.1 CP. Desde esta perspectiva, la violencia psicológica o intimidación consistiría en la amenaza de uso de la violencia física. A través de esta limitación de la violencia típica del delito de rebelión a la violencia física y a la psicológica se evita que este medio comisivo pierda completamente sus referentes empíricos.

75 Como señala Mir Puig, S.: "El delito de coacciones en el Código penal", en Anuario de Derecho Penal y Ciencias Penales, n ${ }^{\circ} 30-2,1977$, pp. 274 y ss., dentro del proceso de progresiva espiritualización del concepto de violencia, se han incluido en éste, no sólo como formas indirectas de intimidación de una persona, actos de fuerza en las cosas. Incluso actos que ni siquiera son propiamente de fuerza en las cosas, toda vez que en ellos éstas tan sólo se ponen fuera del alcance del perjudicado, impidiéndose su legítimo goce y disfrute. 
La violencia del alzamiento también puede ser psicológica al no existir óbice alguno para que la amenaza del uso de la violencia física lesione el bien jurídico. Difícilmente podría decirse que un golpe de Estado en el que el ejército se ha desplegado por todo el territorio y ha ocupado las calles, las principales infraestructuras de transporte y comunicación y las sedes de la mayoría de poderes públicos, no ha generado un riesgo jurídico-penalmente relevante para el orden constitucional por la circunstancia de no haberse materializado ningún acto de violencia física. Para que una sublevación militar de estas características amedrente gravemente a los representantes del poder legalmente constituido, ni siquiera sería necesaria una verbalización o explicitación del anuncio del mal. Según ello, la intimidación puede ser incluso ambiental cuando la amenaza se desprende del propio contexto en el que se desarrolla el alzamiento.

Puede implicar una amenaza superior para el sistema constitucional un alzamiento militar sin violencia física con amplia implicación de los distintos poderes del Estado, incluidos los diferentes mandos de las Fuerzas Armadas, que otro escasamente secundado de carácter marginal y fácilmente erradicable, aunque en él se haya ejercido violencia física sobre algunas personas $^{76}$. Así pues, en el delito de rebelión resulta necesaria una cierta espiritualización del concepto de violencia para, a través de la admisión de la intimidación como medio comisivo, adaptar el radio de acción del tipo a las finalidades de protección del mismo. Esta ampliación de la noción de violencia a formas distintas de la violencia física, pese a acarrear una innegable extensión del concepto, no implica una volatilización o desvanecimiento del mismo por cuanto éste se dota de referentes empíricos claros.

Según ello, la rebelión también podría tener lugar por medio de actitudes inequívocamente conminatorias capaces de

76 En la misma línea, Morillas Cueva, L.: Sistema de Derecho penal. Parte especial, Madrid, 2016, p. 1249. 
doblegar la voluntad de los representantes del poder legalmente constituido, al margen de que se exterioricen o no a través de expresiones verbales (orales o escritas). Todo ello sin perjuicio de que, cuanto más consolidado esté el Estado constitucional en cuestión, mayores sean las exigencias para considerar que la conducta puede afectar en términos jurídico-penalmente relevantes al bien jurídico protegido, al ser también menos los supuestos en los que el Estado puede verse en la necesidad de decretar el estado de sitio. Esta interpretación "dinámica" del delito de rebelión, modulable en función del contexto espaciotemporal en el que se inserte ${ }^{77}$, sería coherente con la atribución a la dogmática jurídico-penal de funciones relativas a la racionalización, control y limitación de las tendencias punitivas orientadas a la protección de la sociedad a través de la expansión del Derecho penal ${ }^{78}$.

77 Desde esta perspectiva, el delito de rebelión se acercaría a los delitos a los que generalmente se atribuye carácter contextual al depender la relevancia penal del comportamiento de las circunstancias periféricas o ambientales en las que se desarrollan los hechos. Así, en relación con el delito de enaltecimiento del terrorismo del art. 578 CP, en la STS 948/2016, de 15 de diciembre, se condena al acusado, por unas expresiones proferidas en diversas redes sociales entre los años 2010 y 2014, al constatarse que la conducta se ejecutó en un contexto social y político y en un territorio en el que todavía no se había estabilizado un clima de convivencia pacífica que excluyera de manera definitiva el coloquialmente denominado "terrorismo de baja intensidad". Por su parte, respecto los delitos contra el honor, en las STS 161/2015, de 17 de marzo; 224/2010, de 3 de marzo; 585/2007, de 20 de junio; 812/2011, de 21 de julio; 31/2011, de 2 de febrero, se establece que, para determinar si la conducta es efectivamente humillante, hostil o vejatoria, es importante, no sólo el tenor literal de las expresiones pronunciadas, sino también su contexto o circunstancias concomitantes, al admitir el lenguaje ordinario interpretaciones diversas, lo que obliga a averiguar cuál de los posibles significados ha sido utilizado en cada ocasión concreta.

$78 \mathrm{Al}$ respecto comparto plenamente las observaciones de JiMÉNEZ DíAz, M. J.: "Sociedad del riesgo e intervención penal", en Revista Electrónica Ciencia Penal y Criminología, no 16-08, 2014, p. 20: "en el contexto actual, pretender que el Derecho penal se muestre insensible a la evolución social es de todo punto impensable. El orden punitivo, como el resto del Ordenamiento jurídico, es un mero instrumento al servicio de la sociedad y de sus ciudadanos y, como tal, debe adaptarse a los tiempos en los que debe ser aplicado. 
Con una especificación de las concretas formas de violencia incriminadas por el delito de rebelión en el tenor literal del tipo, se alcanzaría un mayor grado de certeza y seguridad en orden al conocimiento de la materia de prohibición, con el consiguiente apuntalamiento de la eficacia preventiva de la norma primaria, lo que a su vez limitaría el arbitrio judicial a los efectos de que éste no pueda ejercer funciones propias del poder legislativo. En cualquier caso, los promotores de la sublevación por lo menos deben amenazar con el uso de la violencia física en caso de que no se acceda a sus pretensiones, por lo que deben exteriorizar un propósito terminante de conseguir sus objetivos por cualquier medio o procedimiento a través de la exhibición de una actitud amenazadora de carácter público, patente, palpable y conocida por todos ${ }^{79}$.

En la historiografía española abundan ejemplos de sublevaciones militares perpetradas sin violencia física. Algunas de ellas incluso triunfaron como el golpe de Estado del general Pavía de 1874, con el que se liquidó la Primera República; el

Partiendo de esta premisa el Derecho penal no puede ni debe acorazarse en torno al núcleo tradicional, convirtiéndose en un cuerpo normativo obsoleto, incapaz de afrontar las nuevas demandas sociales. Muy al contrario, debe evolucionar y hacer frente, junto a los peligros clásicos, a los nuevos riesgos que vayan apareciendo. La cuestión radica en que la inevitable expansión del Derecho penal se haga correctamente y no desemboque en un intervencionismo penal desmedido, mediante el que se lleve al ámbito del Derecho punitivo todo aquello que no sabe resolverse con otros instrumentos que podrían resultar adecuados o, lo que es peor, que no quiera solucionarse con esos otros instrumentos, sencillamente, porque el orden penal sale mucho más barato y es más impactante de cara a la opinión pública. Porque esa inadecuada Política criminal, irremediablemente acaba desembocando en una utilización simbólica del Derecho penal y termina por decepcionar a todos aquellos ciudadanos que, aunque inicialmente, se dejaron impresionar positivamente por la elección de la vía penal para resolver determinados problemas, al final se dan cuenta de que ese camino, en muchos de los casos, no sirve para nada".

79 En la misma línea, en la STS de 22 de abril de 1983, se establece que la violencia física no es un requisito indispensable del delito de rebelión, al bastar con la violencia psicológica. 
de los generales Martínez Campos y Dabán -conocido como "pronunciamiento de Sagunto"-, mediante el que se reinstauró la Monarquía borbónica en diciembre del mismo año; o el del general Primo de Rivera de 1923. Como es obvio, los autores de tales sublevaciones realizadas sin violencia física no fueron sometidos a juicio en atención al carácter triunfante de las mismas. Según ello, la deposición de las armas en el curso de la rebelión sin antes haber hecho uso de las mismas no puede integrar una forma de desistimiento voluntario ni, por lo tanto, determinar la atipicidad de la conducta desde la óptica del delito de rebelión. En estos casos no puede afirmarse, en definitiva, que el bien jurídico no se haya colocado en una zona de incertidumbre penalmente significativa.

Así pues, la intimidación es suficiente para satisfacer las exigencias típicas del delito de rebelión cuando los sublevados no puedan asegurar que su alzamiento, con toda seguridad, discurrirá sin violencia física. En esta línea, como señala el TS, el golpe de Estado del 23-F no puede considerarse una rebelión pacífica (sin intimidación), aunque los insurgentes hubieran acordado que la operación sería incruenta, a la vista de que todos ellos portaban armas y de que la entrada del teniente coronel Tejero en el hemiciclo del Congreso, con las fuerzas de la Guardia Civil, fue preludiada y apoyada con diversos disparos de metralleta, por más que éstos se dirigieran al techo de la referida sala ${ }^{80}$.

Curiosamente, la técnica legislativa empleada en el delito de rebelión, mientras que en algunos aspectos es excesivamente abstracta, como en lo referente a la definición del concepto de violencia, en otros pasajes de la descripción típica es demasiado

80 Como señala Sandoval, J. C.: El delito de rebelión. Bien jurídico y conducta típica, Valencia, 2013, pp. 333 y 334, en el 23-F se ejecutó un alzamiento rebelde caracterizado esencialmente por la intimidación, a través del secuestro de los miembros del Gobierno y del Congreso y del bando dictado por Milans del Bosch, puesto que los zarandeos y zancadillas al teniente general Gutiérrez Mellado, pese a realizarse contra un miembro del Gobierno de la Nación, no tuvieron una trascendencia capaz de convertir en física la violencia psicológica del alzamiento perpetrado. 
casuística ${ }^{81}$. En esta línea, la concreción de los diferentes propósitos que pueden perseguir los agentes resulta en cierta medida reiterativa al producir todos ellos el primero de los señalados, esto es, la derogación, suspensión o modificación, total o parcial, de la Constitución ${ }^{82}$. Asimismo, esta forma de redacción podría generar algunas lagunas de punibilidad al dificultar el castigo de conductas que indudablemente podrían poner en peligro la subsistencia del orden constitucional democrático, pero que persiguen objetivos no previstos en el art. $472 \mathrm{CP}$, como disolver el Consejo General del Poder Judicial o el Tribunal Constitucional, a no ser que se considere que los fines consignados en el tipo conforman un sistema de "numerus apertus".

81 Obviamente, los conceptos legales no pueden alcanzar, por impedirlo su propia naturaleza, una claridad y precisión absolutas. Según ello, la pluralidad de interpretaciones de los enunciados legales resulta inevitable, toda vez que el propio lenguaje es relativamente vago y versátil, de modo que las normas han de ser necesariamente abstractas pese a remitirse implícitamente a una realidad sensible subyacente. Según señala LASCURAín SÁNCHEZ, J.A.: Sólo penas legales, precisas y previas: el derecho a la legalidad penal en la jurisprudencia constitucional, Pamplona, 2009, p. 95, "las normas han de ser precisas, pero a la vez son endógenamente imprecisas y además, en alguna medida, deben serlo. La pregunta constitucional es ahora la de dónde está el límite de la interdicción de la indeterminación".

La seguridad jurídica exige que las normas penales describan con precisión en qué consiste la conducta infractora, cuáles son los requisitos para su sanción y en qué consiste ésta. Sin embargo, una determinación extrema es, no sólo imposible, sino también inconveniente. Es imposible porque el legislador utiliza un material impreciso como es el lenguaje. Y es inconveniente porque una particularización excesiva multiplicaría las leyes, las haría menos cognoscibles y pondría en riesgo su carácter general y el tratamiento igual de los ciudadanos. Asimismo, la norma precisa es más rígida, menos flexible para la adopción de una solución justa adaptada a las circunstancias concretas del caso.

82 Los déficits de certeza y cognoscibilidad de la norma se agravan hasta el paroxismo cuando en el supuesto de hecho de un mismo tipo de delito se yuxtaponen entre sí las técnicas casuísticas y abstractivas de signo más radical. Ello se plasma en una gran profusión de modalidades típicas, algunas de ellas superfluas o redundantes, con el fin de que el delito en cuestión abarque toda la casuística imaginable de supuestos en los que puede producirse un ataque al bien jurídico. Exhaustividad en la descripción de las diversas hipótesis delictivas a la que se añade una o varias modalidades con vocación 
Indudablemente, la referencia explícita al carácter violento del alzamiento en el tenor literal del delito de rebelión pretende acotar el objeto de la prohibición, en el sentido de restringirlo a las conductas más aflictivas para el interés tutelado a través de su adscripción a la categoría de los delitos de medios comisivos determinados. Ahora bien, esta pertenencia a esta clase de delitos resulta meramente nominal o formal si la mención al concepto de violencia se normativiza hasta el extremo de no ser garantía de una mayor gravedad del comportamiento típico. Desde este punto de vista, la referencia explícita en el precepto a la violencia, si pierde todo contacto con los referentes empíricos que deberían sustentarla, es decir, con los fenómenos del mundo sensible con los que se relaciona, carece de toda capacidad descriptiva del objeto de prohibición $y$, por tanto, de cualquier eficacia restrictiva de la tipicidad ${ }^{83}$.

omnicomprensiva o totalizadora, en atención al elevado nivel de abstracción o normativización de sus componentes, la cual opera como cláusula de cierre del sistema o como modalidad de recogida a los efectos de alcanzar una protección penal completa y sin fisuras.

La multiplicidad de formas que puede revestir la conducta delictiva, unida a la especial abstracción de alguna o algunas de ellas, normalmente redunda en un adelantamiento de las barreras de protección, lo que motiva que en estos tipos sea prácticamente imposible apreciar supuestos de tentativa o de actos preparatorios impunes, al castigarse todo contacto entre la conducta y el bien jurídico por remoto que éste sea, es decir, por más lejana o imprevisible que sea la posibilidad de lesión del interés tutelado.

Como ejemplo de abuso simultáneo de las técnicas del casuismo y la abstracción podría citarse el delito de blanqueo de capitales. En él se mencionan expresamente cinco verbos típicos: adquirir, poseer, utilizar, convertir o transmitir. Y, por otro lado, una cláusula general: la realización de "cualquier otro acto" de blanqueo. Sobre ello, vid. del Carpio-Delgado, J.: "Sobre la necesaria interpretación y aplicación restrictiva del delito de blanqueo de capitales", en InDret, n $^{\circ}$ 4, 2016, p. 2.

83 El Derecho, de no concebirse como algo estático, sino como algo en continua regeneración en consonancia con los cambios que se producen en la realidad social, no se agota en la ley escrita, por cuanto ésta sólo constituye un "modelo de regulación" que en el caso concreto ha de ser dotado de contenido preciso por la jurisprudencia. Desde esta perspectiva, el Derecho se concibe como un programa de ordenación configurado en sí mismo como un sistema de decisión tendente a asegurar su propia continuidad y, a la vez, 
Así pues, una previsión genérica de la violencia en la redacción del tipo, sin concretar las específicas manifestaciones de la misma incriminadas, podría repercutir en una vulneración de los principios reseñados ${ }^{84}$. Una vulneración que se intensifica con determinadas interpretaciones jurisprudenciales de la categoría que tienen a funcionalizarla hasta desvanecer completamente la carga axiológica que la violencia podría aportar al tipo en orden, no sólo a los efectos que ésta provoca, sino también a la forma especialmente peligrosa en que éstos se producen. Por este motivo se postula aquí la necesidad de incluir en el tenor literal del tipo una clasificación de las concretas manifestaciones de violencia incriminadas. Con la previsión legal de un catálogo cerrado de las formas de violencia castigadas en relación con cada delito, las posibilidades de la jurisprudencia de vaciar el concepto de contenido sustantivo serían mucho más limitadas ${ }^{85}$.

Un concepto excesivamente amplio de violencia podría suponer una expansión de la esfera de la tipicidad contraria al principio de utilidad. Desde esta perspectiva, la referencia a este

su renovación. Según ello, el Derecho "viviría" y se realizaría en la obra de los jueces, más que en la letra de la ley. Vid. García Amado, J. A.: Teorías de la tópica jurídica, Madrid, 1988, pp. 265 y ss.

84 Sobre la posibilidad de error de prohibición ante normas penales insuficientemente determinadas, Lascuraín Sánchez, J.A.: Sólo penas legales, precisas y previas: el derecho a la legalidad penal en la jurisprudencia constitucional, Pamplona, 2009, pp. 99 y ss.

85 Las tesis defendidas se muestran compatibles con una concepción sustantiva del constitucionalismo que trascienda una visión meramente procedimental del mismo o el simple positivismo jurídico. Si se aboga por una configuración sustantiva o valorativa de la Constitución, la ciencia jurídica se convierte en necesariamente normativa, al tener que elaborarse desde un punto de vista interno a través de la adhesión a los valores constitucionales. Según ello, habría que rechazar un modelo descriptivo de la Constitución como norma, al ser ésta algo más que un conjunto de reglas jurídicas positivas. A través de esta concepción el constitucionalismo pondría en primer plano el objetivo de garantizar los derechos fundamentales. No se limitaría a describir los logros del proceso de constitucionalización, sino que los valoraría positivamente y propugnaría su defensa y ampliación. Vid. ATIEnZA, M.: Fragmentos para una teoría de la Constitución, Madrid, 2007, pp. 117 y ss. 
dato fáctico en el tipo podría ser superflua de no introducir, por su desmedido grado de normativización, una carga semántica adicional en la conducta típica. Y, si esta última no aparece de forma suficientemente diferenciada en sus rasgos esenciales, las posibilidades de conocimiento de la norma primaria del delito en cuestión se reducen por debajo del nivel de incertidumbre soportable desde la óptica del mandato de determinación. En este caso la reacción penal prevista en la correspondiente norma secundaria sería inútil para evitar la lesión del bien jurídico y, por lo tanto, para la protección de la sociedad. Así pues, una intervención penal de esta naturaleza sería ilegítima por su falta de necesidad, esto es, por su ineficacia en orden a la prevención de delitos.

Por otro lado, una exacerbada abstracción del concepto de violencia podría vulnerar el principio de subsidiariedad, habida cuenta de que el círculo de la tipicidad podría ampliarse a ataques contra el bien jurídico-penal inexistentes o penalmente insignificantes con arreglo a los criterios suministrados por el principio de lesividad. En este caso no sería posible albergar una mínima certeza en cuanto a la inexistencia de medios extra-penales eficaces para prevenir estas conductas, con el consiguiente riesgo de que el Derecho penal no opere como un arma de control social subsidiaria o, en otros términos, de que no constituya una ultima ratio $^{86}$. En estos supuestos no podría afirmarse que el Estado ha agotado todos los medios menos lesivos para los derechos individuales que la pena antes de acudir al Derecho penal. Así pues, con esta estructuración del tipo podría erosionarse el carácter fragmentario del Derecho penal, toda vez que con una comprensión tan amplia de la violencia típica no podría asegurarse la limitación de la reacción penal a las modalidades de ataque contra el bien jurídico más peligrosas para éste.

86 Desde la óptica del Estado social, el Derecho penal debe ser un instrumento secundario, en el sentido de que el recurso a la pena para proteger intereses socialmente relevantes aparece como algo extremo. Sobre como el Derecho penal sólo interviene en última instancia, al buscar el mínimo de prevención imprescindible, vid. Mir PuIG, S.: Derecho penal. Parte General, 
El TC ha desarrollado todos estos aspectos al postular que el principio de legalidad penal, como derecho fundamental de los ciudadanos, implica que la definición de los hechos constitutivos de delito y la concreción de las penas a ellos asociadas corresponde al legislador ${ }^{87}$. De esta forma se reconoce a los ciudadanos el derecho a que los delitos y sus penas figuren en la ley al objeto poder adaptar su conducta sin incurrir en responsabilidad penal. La legitimación del Parlamento para definir los delitos y sus consecuencias jurídicas obedece a los graves efectos que las normas penales originan en la libertad individual. Desde esta óptica, sólo podrían ser los representantes electos del pueblo los que ostenten la función de precisar los hechos prohibidos bajo pena. Es por este motivo que el principio de legalidad, en el ámbito sancionador, se encuentra vinculado al modelo de Estado de Derecho que la Constitución enuncia, es decir, "a la autolimitación que se impone el propio Estado con el objeto de impedir la arbitrariedad o el abuso de poder, de modo que expresa su potestad punitiva a través del instrumento de la ley y sólo la ejercita en la medida en que está prevista en la ley". Correlativamente, con el principio de legalidad penal se alcanza una mayor seguridad jurídica, por cuanto permite a los ciudadanos programar, a partir del texto de la ley, sus comportamientos sin

$10^{\mathrm{a}}$ ed., Barcelona, 2015, pp. 117 y ss. Como complemento de lo anterior, Gimbernat Ordeig, E.: Concepto y método de la ciencia del Derecho penal, Madrid, 2009, pp. 25 y ss., sostiene que la privación de libertad a través del Derecho penal supone una intervención tan profunda en la esfera individual que sólo se debe acudir a ella cuando los bienes jurídicos puestos en peligro sean de la máxima envergadura y otra consecuencia jurídica distinta de la pena no ofrezca las mismas garantías de protección: "a un recurso tan radical como la pena sólo se debe acudir cuando el comportamiento se aparte, radicalmente también, de lo que exige el orden social”.

En palabras de Roxin, C.: Política Criminal y estructura del delito. Elementos del delito en base a la Política Criminal, Barcelona, 1992, pp. 34 y ss., el Derecho penal es la ultima ratio de la política social, por lo que no debe imponerse una pena en aquellos casos en los que el Estado tiene a su disposición otros medios menos graves para la superación del conflicto social de que se trate.

87 STC 142/1999, de 22 de julio. 
temor a posibles condenas por actos no tipificados previamente. De esta manera los destinatarios de la norma saben -o tienen al menos la posibilidad de saber- que lo que no está prohibido está permitido, de conformidad con la regla general de la licitud de lo no prohibido.

Del principio de legalidad se deriva entonces una garantía formal, en virtud de la que únicamente cabe imponer una condena por un hecho cuando existe una norma jurídica con un determinado rango (lex scripta), que prevé que tal hecho es punible y que si se realiza le corresponderá una determinada pena, pero siempre que dicha norma jurídica exista con carácter previo a la conducta que es objeto de la condena (lex praevia). Existe, en definitiva, una reserva de ley para definir delitos y para amenazarlos con penas, con la que se acotan las fuentes del Derecho en materia penal.

Ahora bien, la garantía formal que implica el imperio de la ley no basta para asegurar la previsibilidad de las consecuencias jurídicas de los propios actos, ni para garantizar que nadie pueda ser castigado por un hecho no contemplado por la ley. Cabe la posibilidad, históricamente comprobada, de que el legislador o el juzgador desconozcan el sentido de garantía de la ley penal. El primero puede incurrir en ese desconocimiento empleando fórmulas tan vagas e imprecisas que cualquiera pudiera caer inadvertidamente en el ámbito de aplicación de la ley penal, por lo que, aun existiendo ésta, no cumpliría en tal hipótesis su función de advertir qué es lo que está castigado bajo pena. Por su parte, los órganos jurisdiccionales no observan el referido sentido de garantía cuando aplican analógicamente la ley penal a un supuesto no contemplado por ella, aunque semejante. Por estas razones, el principio constitucional de legalidad también comprende una garantía de contenido o material respecto a la ley penal. En relación con el legislador, esa garantía material comporta el mandato de taxatividad o de certeza, que se traduce en la exigencia de predeterminación normativa de las conductas punibles y de sus correspondientes sanciones (lex certa). 
En esta línea, el TC ha declarado que el legislador debe hacer el máximo esfuerzo posible en la definición de los tipos penales, promulgando normas concretas, precisas, claras e inteligibles. Por lo tanto, la ley ha de describir ex ante el supuesto de hecho al que anuda la sanción y la punición correlativa. Expresado con otras palabras, el legislador ha de operar con tipos, es decir, con una descripción estereotipada de las acciones y omisiones incriminadas, con indicación de las simétricas penas o sanciones, lo que exige una concreción y precisión de los elementos básicos de la correspondiente figura delictiva; resultando desconocida esta exigencia cuando se establece un supuesto de hecho tan extensamente delimitado que no permite deducir siquiera qué clase de conductas pueden llegar a ser sancionadas.

Por lo que respecta a los Jueces y Tribunales en su labor de aplicación de las leyes, como reverso o contrapartida del principio de taxatividad o certeza, están también sometidos al principio de tipicidad, en el sentido de que, por un lado, se encuentran en una situación de sujeción estricta a la ley penal y, por otro, les está vedada la interpretación extensiva y la analogía in malam partem, es decir, la exégesis y aplicación de las normas fuera de los supuestos y de los límites que ellas mismas determinan. Según razona el TC, el que estas técnicas jurídicas, que tan fértiles resultados producen en otros sectores del ordenamiento jurídico, estén prohibidas en el ámbito penal y sancionador obedece a que en caso contrario se convertirían en fuente creadora de delitos y penas y, por su parte, el aplicador de la nueva norma así obtenida invadiría un ámbito que sólo corresponde al legislador, en contra de los postulados del principio de división de poderes.

\section{Carga mínima de lesividad de la conducta típica}

Aunque históricamente tanto el delito de rebelión como el de sedición estuvieron sistemáticamente ubicados entre los delitos contra la seguridad del Estado, lo cierto es que en la actualidad ambas figuras delictivas se diferencian entre sí por poner en una situación de peligro abstracto un distinto bien jurí- 
dico: mientras que la rebelión afecta al orden constitucional, al dirigirse contra algunas de las atribuciones fundamentales del Estado, como gobernar y legislar, la sedición tan sólo compromete la aplicación de las leyes o el ejercicio del resto de funciones estatales, lo que la relaciona de forma más directa con el concepto de orden público, al implicar una lesión o puesta en peligro de la función de administrar. Ahora bien, tanto en la rebelión como en la sedición se exige una específica finalidad político-social, consistente, respectivamente, en la voluntad de destruir el Estado democrático y de impedir el normal funcionamiento del mismo ${ }^{88}$. Según ello, el rigor punitivo del delito de rebelión debería quedar reservado para los hechos de mayor entidad, es decir, para aquellos en los que la peligrosidad de la conducta para el bien jurídico sea superior.

Respecto la mínima lesividad de la conducta constitutiva del delito de rebelión, cuanto más consolidado esté un Estado democrático, más reducido será el círculo de conductas ilegales capaces de amenazar su permanencia. Así pues, la previsibilidad de que una conducta lesione el bien jurídico debe analizarse desde las coordenadas históricas actuales, en las que el Estado de Derecho goza de relativa fortaleza institucional tras más de cuarenta años de práctica democrática, sobre todo a la vista de los mecanismos extrapenales de los que dispone para frenar planteamientos políticos que traten de implementarse al margen de los procedimientos legales. Son un claro ejemplo de ello las medidas aprobadas en el año 2017 por el Senado, en virtud del art. $155 \mathrm{CE}$, para forzar a la Comunidad Autónoma de Catalunya a cumplir con lo que se consideró que eran sus obligaciones constitucionales. Incluso en un sistema institucionalmente mucho más frágil como era la II República, en el procedimiento penal seguido contra el Presidente de la Generalitat, Lluís Companys,

88 A juicio de Muñoz Conde, F.: Derecho penal. Parte especial, Valencia, 2017, p. 861, en el delito de sedición las finalidades perseguidas por los alzados no tienen que ser estrictamente políticas, de modo que en él la conducta puede ser menos inquietante para las instituciones políticas fundamentales del Estado. 
por la proclamación de la independencia de Catalunya el 6 de octubre de 1934, cinco magistrados del Tribunal de Garantías Constitucionales discreparon de la mayoría al considerar, mediante los correspondientes votos particulares, que la actuación del acusado, pese a violar formalmente la ley por transgredir las competencias propias de la Generalitat, no constituía un alzamiento rebelde.

Muy probablemente cualquier pronunciamiento militar, sea de la clase que sea (golpes de Estado, alzamientos, revueltas, motines, revoluciones, guerras civiles, etc.), realizado al margen de los cauces legales y dirigido a la consecución de alguno de los fines previstos en el delito de rebelión, cuanto menos va a disponer de una proyección intimidatoria capaz de menoscabar el poder político lícitamente constituido al presentarse como la antítesis paradigmática del Estado democrático y de Derecho. Ahora bien, las posibilidades de destrucción del sistema constitucional a través de amenazas de origen no militar resultan más difíciles de imaginar, sobre todo en un Estado de Derecho razonablemente vigoroso como el nuestro. En cualquier caso, tanto en los alzamientos civiles como en los militares la intensidad lesiva de la conducta debe ser la misma, en el sentido de ser en el caso concreto objetivamente idónea para destruir el orden constitucional.

Cuanto más solidificada se halla la cultura democrática de un país, menores son las posibilidades de subvertir el orden constitucional vigente y, por lo tanto, de enervar el poder legítimamente constituido, esto es, para aniquilar los fundamentos del modelo de Estado hasta el extremo de provocar la desaparición del mismo en cuanto tal. En esta línea, cuanto más asentado está un sistema constitucional, mayores son los instrumentos de los que el mismo dispone para neutralizar las eventuales amenazas que lo acechen, con la consiguiente reducción del círculo de conductas idóneas para dar lugar a un delito de rebelión ${ }^{89}$.

89 En unos términos parecidos, a propósito del delito de provocación a la violencia, la discriminación y el odio del art. 510 CP, AlcÁcer Guirao, R.: "Discurso del odio y discurso político. En defensa de la libertad de los 
Como se ha indicado, los alzamientos que no sea previsible que desemboquen en una declaración de estado de sitio, ni en actos de fuerza física, no suponen una amenaza de suficiente entidad para la pervivencia del marco de convivencia actual. Así pues, desde la óptica del delito de rebelión, los alzamientos respecto los que sea razonable esperar que podrán ser sofocados acudiendo a mecanismos legales distintos de la declaración de estado de sitio, como podría ser el previsto en el art. $155 \mathrm{CE}$, deben reputarse atípicos en virtud del principio de insignificancia al no implicar un peligro suficientemente grave de derogación de la Constitución (o, directamente, por ausencia de riesgo objetivo para el bien jurídico $)^{90}$. El propio TC realiza una función nomofiláctica mediante la que expulsa del Ordenamiento las normas que conculcan el marco constitucional.

Desde esta perspectiva, todos los fines aptos para impulsar la rebelión típica se sintetizan o reconducen a través del previsto en el primer inciso del art. $472 \mathrm{CP}$ : derogar, suspender o

intolerantes", en Revista Electrónica de Ciencia Penal y Criminología, $\mathrm{n}^{\circ}$ 14-02, 2012, pp. 16 y ss., sostiene que esta modalidad delictiva debe interpretarse restrictivamente porque en una sociedad democrática y pluralista es difícil que la incitación al odio presente la carga mínima de lesividad requerida por el tipo, esto es, que se realice con una intensidad tal que sea previsible la realización inminente de actos lesivos para los miembros del grupo social concernido. El autor expresa ideas similares, entre otros artículos, en AlCÁCER Guirao, R.: "Diversidad cultural, intolerancia y Derecho penal", en Revista Electrónica de Ciencia Penal y Criminología, n ${ }^{\circ} 18-11,2016$, pp. 43 y ss.; Alcácer Guirao, R.: "Victimas y disidentes. El 'discurso del odio' en EE.UU. y Europa", en Revista Española de Derecho Constitucional, $\mathrm{n}^{\circ}$ 103, 2015, pp. 74 y ss.; o AlCÁCER GUIRAO, R.: "Libertad de expresión, negación del Holocausto y defensa de la democracia. Incongruencias valorativas en la jurisprudencia del TEDH", en Revista Española de Derecho Constitucional, $\mathrm{n}^{\circ}$ 97, 2013, pp. 311 y ss.

90 Esta conclusión puede apoyarse en el dato de que no resulta penalmente punible cualquier expresión de violencia, sino solo la que desborda los límites de lo socialmente adecuado, lo que ocurre cuando la violencia pasa a ser socialmente anormal o disfuncional o, en otros términos, insoportable para las mínimas condiciones de vida social que trata de garantizar el Derecho penal. Vid. Mir Puig, S.: "El delito de coacciones en el Código penal", en Anuario de Derecho Penal y Ciencias Penales, nº 30-2, 1977, p. 270. 
modificar total o parcialmente la Constitución. Por lo tanto, en todas las modalidades típicas de rebelión la conducta debe ser en el momento de emprenderse adecuada para producir estos efectos $^{91}$. Consiguientemente, en el alzamiento rebelde la violencia, sea física o psicológica, debe ser especialmente intensa tanto en términos cuantitativos como cualitativos, con independencia de que vaya o no acompañada de levantamiento de tropas. Ahora bien, la admisión de la intimidación como forma de violencia susceptible de dar lugar al delito de rebelión no implica que el alzamiento tenga que ser armado. La intimidación como forma de violencia sería la propia del delito de amenazas del art. 169 $\mathrm{CP}$, por lo que el anuncio del mal contra la indemnidad de alguno de los bienes jurídicos enunciados en este precepto podría hacerse por cualquier medio, de forma oral o escrita, expresa o tácita. Según ello, para amedrentar a los destinatarios de la intimidación en ningún caso sería necesaria la utilización efectiva ni la exhibición de instrumentos específicamente concebidos para el ataque $u$ otros medios peligrosos ${ }^{92}$. Desde este punto de vista, podría concebirse un alzamiento civil no armado capaz de derrocar el gobierno legítimo a través de la intimidación ${ }^{93}$.

91 Como afirma Sandoval, J. C.: El delito de rebelión. Bien jurídico y conducta típica, Valencia, 2013, pp. 393 y ss., el primero de los "fines" del alzamiento, consistente en "derogar, suspender o modificar total o parcialmente la Constitución", resume el resto de intenciones rebeldes y, al mismo tiempo, designa el presupuesto de hecho previsto para implementar el estado de sitio.

92 En las legislaciones penales de algunos países se exige explícitamente que el alzamiento sea armado, como ocurre con el art. 346 del CP peruano, el art. 125 del CP colombiano o el art. 121 del CP chileno, ubicados, respectivamente, entre los delitos "contra los poderes del Estado y el orden constitucional", "contra el régimen constitucional" y "contra la seguridad interior del Estado".

93 Mostrándose favorables a esta tesis, Ganzenmüller Roig, C. / Escudero Moratalla, J. R. / Frigola Vallina, J.: Delitos contra la Administración Pública; contra la Administración de Justicia, y contra la Constitución, Barcelona, 1998, p. 786, estima que el delito de rebelión supone un "levantamiento de tropas" capaz de generar una guerra civil. 
Sin embargo, como se ha indicado, el tipo se consuma sin necesidad de que la sublevación liquide efectivamente la organización democrática del Estado y, por lo tanto, de que se materialicen las aspiraciones de los autores. Ahora bien, al margen de lo anterior, quedaría por dilucidar la cuestión de si una actividad o acto parlamentario manifiestamente inconstitucional dispone de suficiente intensidad lesiva como para dañar el núcleo del sistema de convivencia inherente a nuestro régimen jurídicopolítico, incluso en el supuesto de que esa acción político-legislativa vaya seguida de un apoyo social masivo exteriorizado a través de manifestaciones y protestas multitudinariamente concurridas ${ }^{94}$. Asimismo, cabría preguntarse si la acción de un movimiento institucional y social de estas características puede crear un clima o contexto de tácita intimidación ambiental que cerciore la voluntad de los responsables de las instituciones del Estado $^{95}$. Al respecto, me limitaré a apuntar que para la comisión de un delito de rebelión no puede bastar con la aprobación de una ley manifiestamente inconstitucional, al formar parte los controles de validez de la norma realizados por el TC de la actividad ordinaria del Estado. Ni tampoco con que la conducta de los sujetos sea incompatible con alguno de los pronunciamientos

94 La jurisprudencia se decanta por considerar que no pueden ser constitutivos de un delito de rebelión o sedición, o de preparación de los mismos, actos parlamentarios carentes de efectos jurídicos. Por lo tanto, éstos deben conceptuarse como meros posicionamientos políticos de los que no se deriva consecuencia jurídica alguna, por lo que deben encuadrarse en el derecho a la libertad ideológica y de expresión de aspiraciones o anhelos políticos. Según se dispone en el AAN de 8 de febrero de 2016, estos actos deben quedar circunscritos en el ámbito propio y específico del legítimo debate político e ideológico, en los términos en los que éste ha sido definido por el Alto Tribunal (STC 62/2011, de 5 de mayo). Así pues, de acuerdo con la doctrina constitucional, cualquier programa político no violento queda amparado por la libertad ideológica y por el derecho a defender cualquier idea u objetivo político de manera pacífica.

95 Una parte de la doctrina rechaza la admisión de formas de intimidación táctica o ambiental en el delito de rebelión, al considerar que la violencia tiene que ser "abierta". Muñoz Conde, F.: Derecho penal. Parte especial, Valencia, 2017, p. 786. 
del TC, al disponer el Estado de otros medios para garantizar la indemnidad de los aspectos esenciales del régimen políticojurídico vigente.

En cuanto a las manifestaciones ciudadanas, aunque sean de carácter violento y se preparen y ejecuten con alguno de los fines previstos en el delito de rebelión, lo más sensato sería contemplarlas como una tentativa irreal desde la óptica de esta figura si en el momento de realizarse son objetivamente inidóneas para comprometer la existencia del Estado por tratarse en realidad de intentos burdos de demolerlo. En este supuesto a lo sumo podrían ser constitutivas de un delito de sedición si pueden afectar al normal desarrollo de algunas de las funciones del Estado ${ }^{96} \mathrm{o}$, en su caso, de un delito de desórdenes públicos ${ }^{97}$.

En una visión todavía más restrictiva del delito de rebelión se exigiría que la conducta presente la mayor carga de ofensividad posible, lo que en este ámbito necesariamente debería traducirse en la aptitud del hecho para desembocar en una guerra civil. Incluso podría ser compatible con el tenor literal del tipo la exigencia de que la sublevación tenga naturaleza marcial. Así pues, la posición aquí adoptada, según la que el comportamiento debe ser idóneo para justificar la declaración de un estado de sitio y para derivar en actos de enfrentamiento físico, se situaría en una posición intermedia entre los discursos más reduccionistas y expansionistas de la esfera de la tipicidad en esta figura delictiva. De esta forma se evita dejar fuera del radio de acción

96 No toda actuación fuera de las vías legales que cumpla con el resto de los requisitos del tipo de sedición puede equipararse valorativamente a la violencia, ni por lo tanto ser constitutiva de este delito de sedición, en contra de lo que estima la STS de 10 de octubre de 1980. Por otro lado, según se ha expuesto, lo que diferencia el delito de rebelión del de sedición no son los medios comisivos, sino la naturaleza del bien jurídico y la entidad de los ilícitos fines perseguidos por los agentes.

97 La interpretación del orden público conforme a los valores constitucionales necesariamente ha de referirse al orden que permite a los ciudadanos el ejercicio de derechos constitucionales, según señalan Vives ANTón / CARBONELL Mateu, "Delitos contra el orden...", p. 1024. 
de este delito actos en los que la lesión del bien jurídico, sin ser una consecuencia casi segura de la conducta (como sí lo es en las guerras civiles o las sublevaciones castrenses), no sólo es posible sino que, además, es altamente probable de acuerdo con el correspondiente juicio de peligro.

Los sectores partidarios de conformarse con una menor carga de lesividad de la conducta para integrar el tipo de rebelión suelen incurrir en una exageración de los riesgos de desprotección del bien jurídico, al desconocer, por un lado, la existencia de otros recursos, penales y extrapenales, para punir conductas atentatorias contra el orden constitucional, la paz pública o el normal funcionamiento del Estado ${ }^{98} \mathrm{y}$, por otro, que en un Estado de Derecho fuerte como el nuestro, en el que se prevén otros mecanismos de autoconservación eficaces, el círculo de comportamientos idóneos para abolir la Constitución es verdaderamente reducido, incluso entre los que tienen naturaleza militar ${ }^{99}$. Ahora bien, conviene no perder de vista que el delito en estudio está pensado esencialmente para insurrecciones de las Fuerzas Armadas, como demuestra el hecho de que paulatinamente el Código penal militar haya ido arrinconando esta figura hasta reducir su aplicación a los intentos golpistas cuando España se halle inmersa en un conflicto armado internacional (art. 9.2.b. en la redacción dada por la LO 14/2015, de 14 de octubre, sobre el Código penal militar).

Así las cosas, determinados hechos violentos con una relevancia política incontrovertible, aun en el caso de que se acometan con alguna de las finalidades previstas en el art. $472 \mathrm{CP}$, pueden ser atípicos desde el prisma del delito de rebelión de no

98 A favor de limitar el alcance del tipo a movimientos o asonadas militares, ReÁtegui SÁnchez, J.: "Los límites de la conducta típica en la rebelión ¿Es un delito de los 'derrotados' o de los 'triunfadores'?”, en Itaius esto, $\mathrm{n}^{\circ} 1$, 2008, p. 3.

99 Sobre como el delito de rebelión fue inicialmente concebido para punir movimientos militares de personas que disponen de armas, ReÁtegui SÁncheZ, J.: "Los límites de la conducta típica en la rebelión ¿Es un delito de los 'derrotados' o de los ‘triunfadores'?”, en Itaius esto, n 1, 2008, pp. 2 y ss. 
ser jurídico-penalmente relevante el riesgo de que degeneren en una crisis constitucional en los términos descritos. Por ejemplo, si se impide la libre celebración de elecciones municipales en un pequeño pueblo, la conducta realiza formalmente el delito de rebelión (en la modalidad del art. $472.3 \mathrm{CP}$ ), pero no implica un riesgo penalmente significativo de derogación, modificación o suspensión total o parcial de la Constitución.

Uno de los criterios para evaluar la objetiva idoneidad de la conducta para lesionar el bien jurídico del delito de rebelión consiste en valorar si un posterior pronunciamiento del TC serviría para remediar los daños eventualmente infligidos al orden constitucional. Es decir, si la desconexión respecto el régimen jurídico-político precedente es o no reversible ya que, en caso de serlo, no habría mecanismos para forzar el cumplimiento de las resoluciones dictadas por las instituciones legítimas. La propia jurisprudencia recuerda que el Estado de Derecho dispone de herramientas suficientes para frenar, sin necesidad de acudir en primer término a la vía penal, planteamientos políticos que no se ajusten a los procedimientos y cauces legales, lo que le permite dejarlos sin valor ni efecto alguno ${ }^{100}$. Con esta lectura se garantiza la no incriminación de la disidencia política a través del delito de rebelión ${ }^{101}$.

En esta línea, la Constitución se preocupa de su autoprotección al establecer mecanismos para su propia defensa, como es la "cláusula de orden público" del art. 116.4 CE en virtud

100 AAN de 8 de febrero de 2016.

101 Con una tesis idéntica, el Tribunal Superior de Justicia del País Vasco denegó la admisión a trámite de la querella interpuesta por la Asociación Social y Cultural Foro de Ermua por delito de rebelión contra el Lehendakari Ibarretxe por su Propuesta de Estatuto Político de la Comunidad de Euskadi (también llamado "Plan Ibarretxe") al considerar que las manifestaciones de éste sólo podían interpretarse como la expresión de un deseo o anuncio de una intención de naturaleza política y futuro incierto: "el Estado de Derecho tiene mecanismos suficientes al margen del Derecho penal, para, en esta fase en la que nos encontramos, frenar todo tipo de planteamientos políticos que no se ajusten a los procedimientos y cauces legales y constitucionalmente establecidos" (ATSJPV 11/2005, de 1 de marzo). 
de la que sólo se reconoce al poder legislativo la facultad de declarar, a propuesta del Gobierno, el estado de sitio, como restricción más drástica de derechos fundamentales y libertades públicas orientada a la tutela del Estado democrático y de Derecho cuando éste sea gravemente amenazado. El art. 32 de la LO 4/1981, de 1 de junio, regula la situación que puede dar lugar a dicha declaración, que tiene lugar cuando se produce, o amenaza con producirse, "una insurrección o acto de fuerza contra la soberanía o independencia de España, su integridad territorial o el ordenamiento constitucional, que no pueda resolverse por otros medios". Esta situación fáctica prevista como presupuesto para la declaración del estado de sitio casa perfectamente con la descripción típica del delito de rebelión. En este sentido, ambas instituciones en última instancia aspiran a lo mismo: evitar pasar de una democracia representativa a otra forma política autoritaria.

Lo anterior resalta la estrecha relación existente entre el alzamiento rebelde y el estado de sitio, al configurarse éste como el último instrumento del Estado para defenderse, entre otros ataques, de una insurrección que ponga en crisis el proyecto político establecido en la norma fundamental. Por lo tanto, desde el punto de vista del estado de sitio, las conductas que ponen en peligro el ordenamiento constitucional aptas para motivar su declaración, son, por definición, las descritas en el delito de rebelión. Ello refuerza el convencimiento de que en el delito de rebelión la conducta debe colocar al Estado en una situación límite que legitime el recurso al mecanismo más agresivo del que dispone: el poder militar. Desde esta perspectiva, la idoneidad de la insurrección para provocar una crisis constitucional cuya resolución requiera la declaración de estado de sitio, es un baremo fundamental para calibrar la existencia o no de un verdadero alzamiento rebelde.

Si el delito de rebelión constituye el más grave atentado contra el sistema de relaciones sociales previsto en la Carta Magna, resulta lógico exigir que en él la conducta sea capaz de justificar el recurso al estado de sitio, al ser éste un mecanismo diseñado para hacer frente a situaciones extremas en las que 
directamente está en juego la supervivencia del ordenamiento constitucional. Ahora bien, lo anterior es compatible con identificar ciertas similitudes estructurales entre la rebelión y la sedición, al constituir ambas tipologías delictivas "alzamientos" que persiguen determinados "fines" y tener los objetivos sediciosos una cierta relevancia político-social. En la sedición, pese a no cuestionarse la división de poderes o la legitimidad del gobierno de turno, no se actúa con fines estrictamente "privados" al albergar los autores la voluntad de quebrantar de algún modo el orden político o social, por las razones que sean, las cuales pueden ser incluso "humanitarias" o "sentimentales" (alzarse violentamente para impedir la ejecución de una orden de expulsión de un extranjero ilegal o el desahucio de las viviendas de un pueblo que va a ser cubierto por las aguas de un pantano).

Así pues, la conducta del delito de sedición simplemente consistiría en unos desórdenes públicos cualificados por la finalidad particularmente lesiva de los agrupados, para cuya consecución los actos realizados se muestran idóneos. En consecuencia, cabría plantear la posibilidad de considerar esta figura un vestigio histórico del pasado cuya permanencia en el Código penal parece discutible, en cuyo caso a lo sumo podría contemplarse como una modalidad agravada del delito de desórdenes públicos.

El alcance del delito de rebelión podría restringirse todavía más con la exigencia de que el alzamiento tenga carácter "armado". De hecho, la tipificación de la rebelión como alzamiento "en armas" para alcanzar ciertos "fines" tiene una larga tradición en la legislación militar, iniciada en el S. XIX y mantenida hasta la actualidad en el Código penal militar vigente. A pesar de que esta tradición no se ha seguido en la legislación común, un sector de la doctrina opina que uno de los rasgos distintivos de la rebelión en "tiempos de paz" (art. 472 CP) es su carácter armado sobre la base de la interrelación entre la insurrección rebelde y el estado de sitio, al configurarse este último como la ultima ratio en la defensa de la Constitución al motivar la intervención de las Fuerzas Armadas. En este sentido, se argumenta que sólo 
considerando que la insurrección debe ser armada tiene sentido la llamada al Ejército que se efectúa a través de la declaración de estado de sitio. Ahora bien, que el legislador esté pensando en una insurrección que no pueda ser reprimida por otros medios que convocando al poder armado del Estado, esto es, sin el concurso de las armas para la represión de la misma, no significa que sólo pueda ser violento un alzamiento público en el que los rebeldes utilicen armas o las exhiban con fines intimidatorios. De la misma forma que puede implementarse este estado excepcional sin que la insurrección sea armada, tampoco debe serlo la que conforma el delito de rebelión. Ello sin negar la gravedad del estado de sitio, al ser su declaración el único mecanismo que permite la irrupción (reglada) del poder militar en el mundo civil, en el sentido de militarizar las relaciones sociales para salvaguardar el entramado político-constitucional democrático.

\section{Conclusiones}

1. La violencia es un elemento vertebrador del delito de rebelión. Pero el tenor literal del mismo se refiere a ella genéricamente, sin concretar cuáles son las específicas manifestaciones de la misma que incrimina, lo que podría ser contrario al principio de legalidad. En concreto, a las exigencias de certeza de la ley penal impuestas por el mandato de determinación y el principio de taxatividad.

2. La indefinición del tipo en cuanto a las específicas expresiones de violencia criminalizadas, aumenta el margen interpretativo del mismo y, simultáneamente, dificulta el acceso a la materia de prohibición, con la consiguiente merma en la eficacia preventiva de la norma primaria. Ello obliga a acudir a parámetros teleológico-funcionalistas para la delimitación del ámbito de la tipicidad.

3. Con este delito no se tutela una suerte de deber de fidelidad de los ciudadanos hacía las disposiciones superiores del Ordenamiento jurídico (Constitución en sentido formal), sino 
los derechos fundamentales y libertades públicas que éstas proclaman (Constitución en sentido material). Consecuentemente, el comportamiento típico debe atentar contra las bases del sistema de convivencia concretadas en la carta de derechos contenida en el art. 10.1 CE que, como manifestaciones del principio de dignidad de la persona, conforman el fundamento de la paz social y del orden político vigente.

4. Esta delimitación del bien jurídico permite establecer la mínima carga de lesividad de la conducta prohibida. Según ello, la actuación de los rebeldes debe ser adecuada para atentar, no contra cualquiera de los principios consagrados en la Constitución de 1978, sino sólo contra los más esenciales desde una óptica individual, como son los de libertad, justicia, igualdad, pluralismo político, respeto a la dignidad de la persona, respeto a la Ley o libre desarrollo de la personalidad.

5. No basta entonces con la infracción de cualquier precepto de rango constitucional, sino que es necesario perturbar el núcleo del sistema democrático a través de la puesta en peligro de alguno de los derechos fundamentales que integran su parte más sustancial. Así pues, en el momento de actuar el levantamiento público y violento debe ser objetivamente adecuado para deponer, suprimir o modificar la forma de gobierno o el régimen constitucional al margen de los procedimientos legales establecidos para ello.

6. En atención a que la conducta típica debe ser objetivamente idónea para liquidar el régimen jurídico-político vigente, ha de ser previsible que derive en una declaración de estado de sitio (aunque ésta no se produzca efectivamente) y en un enfrentamiento físico en caso de oposición a la insurrección. Carecen de esta capacidad lesiva las subversiones contra el orden constitucional que en el momento de realizarse aparecen como susceptibles de ser sofocadas a través de otros mecanismos legales menos limitativos de derechos fundamentales.

7. Dado que el delito examinado se configura como un tipo de peligro abstracto y de mera actividad, la consumación se 
produce sin necesidad de que el riesgo generado o aumentado por la conducta se realice en la efectiva lesión del sistema de convivencia previsto en el Texto Fundamental.

8. Las rebeliones públicas y violentas adecuadas para realizar alguna de las finalidades típicas, pero carentes de la entidad necesaria como para comprometer la existencia del sistema político-jurídico vigente, deben alojarse en otras tipologías delictivas.

9. Puede suponer una mayor amenaza para el bien jurídico un alzamiento público en el que se amenace con el uso de fuerza física que otro en el que ésta se emplee efectivamente. Consecuentemente, la violencia de la rebelión típica puede ser física (en el sentido del delito de homicidio, asesinato o lesiones) o psicológica (en el sentido del delito de amenazas condicionales).

10. El alzamiento con intimidación puede dar lugar al delito cuando por sus características pueda disuadir a las fuerzas del orden de actuar, al tener éstas indicios racionales para albergar la convicción de que cualquier oposición a los planes subversivos convertirá el alzamiento en más peligroso. Según ello, aunque sea de forma tácita, los promotores de la sublevación por lo menos deben exteriorizar una inequívoca intención de conseguir sus objetivos por cualquier medio o procedimiento.

11. El delito en estudio no se configura como un delito especial, pero en el momento presente difícilmente puede imaginarse un alzamiento público y violento de carácter no militar cuya gravedad sea suficiente como para motivar una declaración de estado de sitio. Ello porque, cuanto más consolidado está un Estado de Derecho, más reducido es el círculo de conductas idóneas para destruirlo.

12. Tanto en el delito de rebelión como en el de sedición se exige un levantamiento público y violento, que puede ser o no armado y estar más o menos organizado, si bien en el segundo caso el nivel de conmoción social producido por el hecho es 
menor, al bastar con que la conducta sea adecuada para alterar la normal prestación de determinados servicios públicos.

13. La restricción del tipo a los alzamiento públicos y violentos más graves se muestra acorde con los límites del poder punitivo propios de un Estado social como los emanados de los principios de utilidad, subsidiariedad y ultima ratio. Sólo cuando la conducta pueda motivar una declaración de estado de sitio será posible afirmar que no había medios distintos de los penales para prevenirla.

14. La exigencia de que la rebelión típica tenga carácter marcial o que sea adecuada para provocar una guerra civil, podría reducir en exceso el perímetro de la tipicidad, con la consiguiente creación de lagunas de punibilidad político-criminalmente indeseables. Así pues, pueden ingresar en la esfera del delito de rebelión aquellos comportamientos respecto de cuya evitación los otros medios de control social se revelen ineficaces.

15. Desde una perspectiva subjetiva, todos los fines aptos para animar la rebelión típica se sintetizan o reconducen a través del previsto en el primer inciso del art. $472 \mathrm{CP}$ : derogar, suspender o modificar total o parcialmente la Constitución. Por lo tanto, en todas las modalidades típicas de rebelión la conducta debe ser en el momento de emprenderse adecuada para producir estos efectos.

16. No es necesario que el alzamiento público y violento sea armado, ni que vaya acompañado de levantamiento de tropas. En esta línea, el bien jurídico puede lesionarse sin el uso de instrumentos específicamente concebidos para el ataque. En cuanto a la intimidación, para amedrentar a los destinatarios de la misma en ningún caso es necesaria la utilización efectiva ni la exhibición de armas u otros instrumentos peligrosos.

17. Otro de los criterios para evaluar la objetiva idoneidad de la conducta para lesionar el bien jurídico del delito de rebelión consiste en valorar si un posterior pronunciamiento del TC podría remediar los daños eventualmente infligidos al orden 
constitucional. Es decir, si la desconexión respecto el régimen jurídico-político precedente es o no reversible.

18. La Constitución se preocupa de su autoprotección al establecer mecanismos para su propia defensa. En este sentido, la situación fáctica prevista como presupuesto para la declaración del estado de sitio casa perfectamente con la descripción típica del delito de rebelión. En consecuencia, en última instancia ambas instituciones aspirarían a mantener los rasgos esenciales del actual Estado social y democrático de Derecho mediante la prevención de actuaciones tendentes a instaurar por la fuerza regímenes políticos autoritarios.

\section{Bibliografía}

Ambos, K.: "Bases teóricas para determinar la 'función global' del Derecho penal internacional. Una segunda contribución para una teoría coherente del Derecho penal internacional", en InDret, $\mathrm{n}^{\circ}$ 10, 2013.

Alcácer Guirao, R.: "Discurso del odio y discurso político. En defensa de la libertad de los intolerantes", en Revista Electrónica de Ciencia Penal y Criminología, no 14-02, 2012.

- "Diversidad cultural, intolerancia y Derecho penal", en Revista Electrónica de Ciencia Penal y Criminología, $\mathrm{n}^{\mathrm{o}}$ 18-11, 2016.

- $\quad$ "Facticidad y normatividad. Notas sobre la relación entre ciencias sociales y Derecho penal", en Anuario de Derecho Penal y Criminología, Vol. LII, 1999.

- $\quad$ "Libertad de expresión, negación del Holocausto y defensa de la democracia. Incongruencias valorativas en la jurisprudencia del TEDH”, en Revista Española de Derecho Constitucional, ${ }^{\circ}$ 97, 2013.

- $\quad$ "Taxatividad, reserva de ley y cláusulas de lesividad en las normas penales en blanco. Consideraciones al hilo de la STC 101/2012, de 8 de mayo", en Diario la Ley, $\mathrm{n}^{\circ}$ 7922. 
- $\quad$ "Victimas y disidentes. El 'discurso del odio' en EE.UU. y Europa”, en Revista Española de Derecho Constitucional, $\mathrm{n}^{\mathrm{o}}$ 103, 2015.

Atienza, M.: “Argumentación y Constitución”, en Fragmentos para una teoría de la Constitución, Aguiló Regla / Atienza / Ruiz Manero, Ed. Iustel, Madrid, 2007.

Bustos Ramírez, J.: Manual de Derecho Penal. Parte General, $3^{\mathrm{a}}$ ed., Ed. Ariel, Barcelona, 1989.

Corcoy Bidasolo, M.: El delito imprudente. Criterios de imputación del resultado, $2^{\mathrm{a}}$ ed., Ed. B de F, Buenos Aires, 2005.

DAHL, R.: La democracia y sus críticos, Ed. Paidós, Barcelona / Buenos Aires, 1992.

del Carpio-Delgado, J.: "Sobre la necesaria interpretación y aplicación restrictiva del delito de blanqueo de capitales", en InDret, no 4, 2016.

Dopico Gómez-Aller, J.: “¿Es competente la Audiencia Nacional para conocer de los delitos de rebelión y de (algunos de) los delitos de sedición?", en Revista Electrónica de Ciencia Penal y Criminología, no 19-17, 2017.

Embid Irujo, A.: La constitucionalización de la crisis económica, Ed. Iustel, Madrid, 2012.

Ferreres Comella, V.: El principio de taxatividad en materia penal y el valor normativo de la jurisprudencia (una perspectiva constitucional), Ed. Civitas, Madrid, 2002.

Ganzenmüller Roig, C. / Escudero Moratalla, J. R. / Frigola Vallina, J.: Delitos contra la Administración Pública; contra la Administración de Justicia, y contra la Constitución, Ed. Bosch, Barcelona, 1998.

García Amado, J. A.: Teorías de la tópica jurídica, Ed. Civitas, Madrid, 1988.

García Rivas, N.: "Delitos contra la Constitución”, en Lecciones y materiales para el estudio del Derecho penal, Coord. Terradillos Basoco, Ed. Iustel, Madrid, 2016.

- La rebelión militar en Derecho Penal, Ediciones de la Universidad de Castilla-La Mancha, Albacete, 1990. 
- “ ¿Rebelión en Cataluña? La Fiscalía de la Audiencia Nacional persigue 'sombras rebeldes", en Eunomía, no 10, 2016.

Gimbernat Ordeig, E.: Concepto y método de la ciencia del Derecho penal, $2^{\mathrm{a}}$ ed., Ed. Tecnos, Madrid, 2009.

González Gutiérrez-Barquín, P.: "Delito fiscal. El bien jurídico protegido", en Manual de Delitos contra la Hacienda Pública, Dir. García-Tizón López, Ministerio de Justicia, Madrid, 2004.

GonzÁlez Rus, J.J.: "Delitos contra la Constitución (I)", en Sistema de Derecho penal español. Parte especial, Coord. Morillas Cueva, Ed. Dykinson, Madrid, 2011.

Javato Martín, A.: “¿Existe el delito de sedición en Alemania, Suiza y Bélgica?”, en Diario La Ley, n 9188, 2018.

JiMÉnEz DíAz, M. J.: "Sociedad del riesgo e intervención penal", en Revista Electrónica Ciencia Penal y Criminología, $\mathrm{n}^{\circ}$ 16-08, 2014.

LASCURAín SÁnchez, J. A.: “¿Restrictivo o deferente? El control de la ley penal por parte del Tribunal Constitucional", en Indret, $\mathrm{n}^{\mathrm{o}} 3,2012$.

- Sólo penas legales, precisas y previas: el derecho a la legalidad penal en la jurisprudencia constitucional, Ed. Aranzadi, Pamplona, 2009.

Lopera Mesa, G. P.: Principio de proporcionalidad y ley penal, Centro de Estudios Políticos y Constitucionales, Madrid, 2006.

López Rubio, D.: "El control de constitucionalidad de la 'legislación popular", en Oñati Socio-legal Series, V. 7, n 5, 2017.

Magro Servet, V.: "Casuística práctica y jurisprudencial de los delitos de rebelión y sedición", en Diario La Ley, $\mathrm{n}^{\mathrm{o}}$ 9074, 2017.

Manzanares Samaniego, J. L.: "El Código Penal en el proceso independentista de Cataluña”, en Diario La Ley, n 9061, 2017. 
Martínez Estay, J. I.: “Auto-restricción, deferencia y margen de apreciación. Breve análisis de sus orígenes y de su desarrollo", en Estudios Constitucionales, Vol. 12, n 1, 2014.

Mir Puig, S.: Derecho penal. Parte General, $10^{\mathrm{a}}$ ed., Ed. Reppertor, Barcelona, 2015.

- $\quad$ "El delito de coacciones en el Código penal", en Anuario de Derecho Penal y Ciencias Penales, no 30-2, 1977.

- Introducción a las bases del Derecho penal, $2^{\mathrm{a}}$ ed., Ed. Bosch, Barcelona, 1976.

- "Sobre la punibilidad de la tentativa inidónea en el nuevo Código Penal", en Revista de Derecho Penal y Criminología, $\mathrm{n}^{\circ} 3,2001$.

Moreno-Torres Herrera, M. R.: Tentativa de delito y delito irreal, Ed. Tirant lo Blanch, Valencia, 1999.

Morillas Cueva, L.: "Delitos contra la Constitución (III)", en Sistema de Derecho penal. Parte especial, Dir. Morillas Cueva, $2^{\mathrm{a}}$ ed., Ed. Dykinson, Madrid, 2016.

Muñoz Conde, F. / García Arán, M.: Derecho Penal. Parte General, $8^{\mathrm{a}}$ ed., Ed. Tirant lo Blanch, Valencia, 2010.

Muñoz Conde, F.: Derecho penal. Parte especial, $21^{\mathrm{a}}$ ed., Ed. Tirant lo Blanch, Valencia, 2017.

Musco, E.: "La irracionalidad en el Derecho penal", en Revista Electrónica de Ciencia Penal y Criminología, no 16-1, 2014.

Pawlik, M.: "El delito, ¿lesión de un bien jurídico?”, en InDret, $\mathrm{n}^{\circ} 2,2016$.

Peris Riera, J.M.: "Delitos contra el orden público (I)", en Sistema de Derecho penal. Parte especial, Dir. Morillas Cueva, $2^{\mathrm{a}}$ ed., Ed. Dykinson, Madrid, 2016.

Quintero Olivares, G.: Parte General del Derecho Penal, $2^{\mathrm{a}}$ ed., Ed. Thomson Aranzadi, Pamplona, 2007.

ReÁtegur SÁnchez, J.: "Los límites de la conducta típica en la rebelión ¿Es un delito de los 'derrotados' o de los 'triunfadores'?", en Itaius esto, $\mathrm{n}^{\circ}$ 1, 2008.

Reyes Alvarado, Y.: El delito de tentativa, Ed. B de F, Montevideo / Buenos Aires, 2016. 
Rey Sanfiz, L. C.: La tentativa jurídico-penal. Acercamiento al tratamiento doctrinal del fundamento de los criterios de imputación entre naturalismo y normativismo, Ed. Dykinson, Madrid, 2001.

Roxin, C.: Política Criminal y estructura del delito. Elementos del delito en base a la Política Criminal (trad. Bustos Ramírez y Hormazabal Malarée), Ed. PPU, Barcelona, 1992.

SÁnchez Recio, G.: "La lealtad a la ley convertida en delito de rebelión: la represión de los jueces”, en Aniquilación de la República y castigo a la lealtad, Dir. Sánchez Recio, Ed. Publicaciones Universidad de Alicante, Alicante, 2015.

Sandoval, J. C.: El delito de rebelión. Bien jurídico y conducta típica, Ed. Tirant lo Blanch, Valencia, 2013.

Silva SÁnchez, J.: Aproximación al Derecho penal contemporáneo, $2^{\mathrm{a}}$ ed., Ed. B de F, Montevideo / Buenos Aires, 2010.

- Fundamentos del Derecho penal de la Empresa, Ed. Edisofer / B de F, Madrid / Montevideo / Buenos Aires, 2013. 